107 Royal Netherlands Institute for Sea Research

This is a postprint of:

Cyr, F., \& Larouche, P. (2015). Thermal Fronts Atlas of Canadian Coastal Waters. Atmosphere-ocean, 53(2), 212-236

Published version: $\underline{\mathrm{dx} . \text { doi.org/10.1080/07055900.2014.986710 }}$

Link NIOZ Repository: $\underline{w w w . v l i z . b e / n l / i m i s ? m o d u l e=r e f \& r e f i d=246532 ~}$

[Article begins on next page]

The NIOZ Repository gives free access to the digital collection of the work of the Royal Netherlands Institute for Sea Research. This archive is managed according to the principles of the Open Access Movement, and the Open Archive Initiative. Each publication should be cited to its original source - please use the reference as presented.

When using parts of, or whole publications in your own work, permission from the author(s) or copyright holder(s) is always needed. 
To appear in Atmosphere-Ocean

Vol. 00, No. 00, mm уyyy, 1-52

1

\section{Thermal fronts atlas of Canadian coastal waters} and Oceans Canada, Mont-Joli (Québec) Canada; 
Oceanic fronts are often associated to enhanced biological activity. Depending on their generation mechanism, they are often linked to specific geographical areas. Here we use 25 years of high-resolution satellite sea surface temperature (SST) daily images to generate maps of SST fronts over the Canadian coastal waters. Results show that fronts are ubiquitous features but some fronts are more persistent than others. We confirmed the location of already known major fronts but some new persistent frontal areas have also been detected as a result of the use of high-resolution $(1.1 \mathrm{~km})$ data and a methodology adapted to detect smaller-scale frontal features. Results also show that some of the frontal areas are associated to enhanced phytoplankton biomass or higher trophic level organisms (whales, birds) confirming the ecological importance of this physical process.

Les fronts océaniques sont souvent liés à une activité biologique accrue. Ils sont souvent associés à une aire géographique spécifique qui dépend du mécanisme qui les génèrent. Nous avons utilisé 25 années d'images journalières de températures de surface de la mer (TSM) à haute résolution spatiale afin de générer de cartes de fronts de TSM pour les eaux côtières canadiennes. Les résultats montrent que des fronts sont visibles partout mais que certains d'entre eux sont persistants dans le temps. Nous avons confirmé la position des fronts déjà connus mais de nouvelles zones ont aussi été détectés résultant de l'utilisation de données à haute résolution $(1.1 \mathrm{~km})$ et d'une méthodologie adaptée à la détection de fronts à plus petite échelle spatiale. Les résultats ont aussi montré que certains fronts sont associés à une biomasse phytoplanctonique plus élevée ou à la présence d'organismes de niveaux trophiques supérieurs (baleines, oiseaux), confirmant l'importance écologique de ce processus physique.

KEYWORDS: Thermal fronts, Frontal probability, Newfoundland Shelf, Scotian Shelf, Gulf of St. Lawrence, Hudson Bay, Baffin Bay, Pacific Ocean 


\section{Introduction}

An oceanic thermal front is a region of enhanced sea surface temperature (SST) gradients. They are often linked to gradients of other physical, chemical or biological properties such as salinity, nutrients, plankton, suspended sediments, etc. Their spatial and temporal scales vary over many orders of magnitude, ranging from small river plumes (few meters and a lifetime of few days) to western boundary currents such as the Gulf Stream (hundreds of kilometers, and coherent in time for thousands of years). Because ocean fronts often constitute exceptional biological habitats, they are considered a key feature in physical oceanography (Belkin, Cornillon, and Sherman, 2009; Sherman, 1990, 2005).

Past studies mostly concentrated on the description of large-scale oceanic fronts associated with major currents (e.g. Belkin et al., 2009; Bisagni, Kim, and Chaudhuri, 2009; Legeckis, Brown, and Chang, 2002). Only a few studies focused on specific coastal ecosystems (e.g. Belkin, Cornillon, and Ullman, 2001; Nieto, Demarcq, and McClatchie, 2012; Wall, Muller-Karger, Roffer, $\mathrm{Hu}$, Yao, and Luther, 2008). Many physical processes such as geostrophic currents, estuarine buoyancy currents, upwellings, water masses convergence zones or marginal ice zones can generate fronts in the coastal ocean. Depending on the generation mechanisms, fronts are often closely related to bathymetric features (shelves, capes, canyons, banks, shoals, etc.). The generation mechanisms also determine if the front will be associated with surface nutrient supply and enhanced primary productivity. For example, fronts delimiting divergence zones (such as tidal mixing or upwelling) from the surrounding waters generally mark high primary productivity areas. On the other hand, fronts associated with current convergence, or with temperature gradient caused by river plumes or ice melting, may not be associated with high nutrient supply.

Surrounded by three oceans, Canada has the longest coastline in the world and oceans have a primary role in Canadian economy generating more than $1 \mathrm{~B} \$$ of revenues. However, such large body of water makes it difficult to monitor in details from conventional in situ observations. Moreover, the remoteness and the harsh ice and meteorological conditions that prevail in most of the northern basins makes observational datasets in these areas very scarce. Although a few 
studies have looked at frontal structures in Canadian waters from satellite data (e.g. Jardine, Thomson, Foreman, and Leblond, 1993; Lavoie, Bonn, Dubois, and El-Sabh, 1985; Mavor and Bisagni, 2001; Perry, Dilke, and Parsons, 1983; Ullman and Cornillon, 1999), these are generally limited to small areas. Using 25 years of remote sensing sea surface temperature (SST) data, the aim of this study is thus to provide an overview of frontal features in Canadian coastal waters. Whenever possible, known associations between front location, generation mechanism and biological features are also indicated.

This study is therefore an atlas for front location to which scientists can refer in preparation to (or complement to) field studies. This work may also help in mapping sensitive biological habitat in a changing environment, such as the work recently realized by the World Wildlife Fund (Sommerkorn, 2012). Seven regions are under the scope of this study: Hudson Strait and Labrador Shelf, Newfoundland Shelf, Scotian Shelf and Gulf of Maine area, Gulf of St. Lawrence, Hudson Bay and Foxe Basin, Baffin Bay and Northeast Pacific Ocean (Fig. 1). For rapid information seeking, each of these regions is presented and discussed separately in sub-sections 3.a to 3.g. These regions are mostly in Canadian waters, but some regions naturally close to Canada will also be described. The Beaufort Sea (hatched area in Fig. 1) is not discussed here since the region is under investigation in another ongoing and independent study on thermal fronts.

\section{Methodology and datasets}

Mean daily maps of sea surface temperature (SST) were obtained from the Maurice Lamontagne Remote Sensing Laboratory for the period 1985-2010. These maps were generated using Advance Very High Resolution Radiometer (AVHRR) data. These daily SST maps are composites of multiple satellite passages over Canadian waters with a spatial resolution of $1.1 \mathrm{~km}$. Before compositing, each image goes through a thorough series of tests to eliminate clouds and ice. These tests are based on pixel albedo in the two visible channels and temperature in the three thermal channels. Tests are also made on the spatial uniformity of albedo and temperature over a $3 \times 3$ pixel box. These flagged data are then compared to ice coverage maps generated by the 
National Snow and Ice Data Center (NSIDC) to detect abnormal pixels that could have gone undetected through the cloud screening. Any SST pixel corresponding to a non-zero ice coverage region according to NSIDC is flagged as ice covered. A final test is done to further eliminate abnormal values that may have gone through cloud/ice screening. This is done by first applying a temporal homogeneity filter that compares SST with all other measurements made during a 15day window centered on the image time. Then, a daily climatological filter is used to eliminates outliers above 3 standard deviations from the 25-year average. The use of a climatological filter has been shown to greatly improve the quality of SST retrievals for mid-latitudes data leading to a mean bias of $-0.19^{\circ} \mathrm{C}$ (Pettigrew, Larouche, and Gilbert, 2011).

Regions of interest for this study (Fig. 1) were extracted from the daily national composites and processed for front detection. Before processing images with the front detection algorithm, land was masked using the National Oceanic and Atmospheric Administration's (NOAA) Global Self-consistent, Hierarchical, High-resolution Geography (GSHHG) database (Wessel and Smith, 1996), so that only water pixels were processed. When more than $85 \%$ of the water pixels of a daily image is flagged for cloud, ice or invalid pixel, the image is discarded and not compiled into further analysis. As the goal was to study coastal fronts, we used the variable window single-image edge-detection algorithm (VW-SIED, Diehl, Budd, Ullman, and Cayula, 2002). This algorithm is an improvement of SIED (Cayula and Cornillon, 1992), that is using a fixed overlapping window size for the edge detection. The advantage of VW-SIED is that the variable window size offers better detection of smaller scale fronts (Kahru, Di Lorenzo, Manzano-Sarabia, and Mitchell, 2012) and is thus better suited for the study of coastal regions. The algorithm exploits the idea that for a frontal region, SST pixel values over a certain window should follow a bimodal distribution (many warm and cold pixels with a fewer pixels in the temperature transition range). Fronts generally correspond to this transition zone called edge. To detect fronts, each daily SST image is split into overlapping windows of variable sizes for which SST distributions are calculated and edges flagged. The VW-SIED algorithm optimizes window size using semivariance statistics and the overlap is always half the size of neighboring windows. When all 
the image is processed, individually detected edges that may be disconnected to each other are linked to each other with another algorithm (see contour following in Cayula and Cornillon, 1992). After VW-SIED algorithm processing, our dataset corresponds to daily images indicating front / no front pixels with flagged pixels corresponding to ice or cloud. After front detection, statistics are calculated using all the available images (number of days $\times 25$ years) to generate a frontal frequency index for each pixel defined as:

$$
f(\%)=\frac{\# \text { detected fronts }}{\# \text { cloud } / \text { ice free pixels }} \times 100 \% .
$$

Maps of phytoplankton biomass revealed by chlorophyll (chl- $a$ ) concentration are also presented in this study. This information has been obtained through the Giovanni web portal (http://disc.sci.gsfc.nasa.gov/giovanni) that provides an interactive tool to extract satellitederived chl- $a$. We used that tool to estimate a climatology of chl- $a$ using the global time series of SeaWiFS data (1998-2010). Unless otherwise stated, information about bird colonies locations was gathered from the Important Bird Areas in Canada (www.ibacanada.ca) and from the Canadian Wildlife Service (2012). Finally, bathymetric features have been obtained from the 30 arc-second intervals of the General Bathymetric Chart of the Oceans (GEBCO_08 Grid, version 20100927, http://www.gebco.net).

\section{Observations and discussion}

\section{3.a Hudson Strait and Labrador Shelf}

Hudson Strait, including the Ungava Bay (Fig 2), is a region under the influence of freshwater runoff from Hudson Bay and the high salinity waters of the Labrador Sea (Drinkwater, 1986). This region is known for strong tidal currents and high elevation due to near-resonant $\mathrm{M}_{2}$ frequency that enters into the strait from the Labrador Sea. Oceanic fronts are thus likely to occur in this region as a result of water mass interaction and tidal mixing. After the pioneering work of Griffiths, Pingree, and Sinclair (1981) who mapped tidal fronts from a numerical study of the 
Simpson-Hunter parameter (Simpson and Hunter, 1974), very little field work (e.g., Drinkwater and Jones, 1987; Taggart, Drinkwater, Frank, McRuer, and Larouche, 1989) have been conducted to confirm the existence of these fronts.

Some of the locations where high frontal frequencies are observed corroborates Griffiths et al. (1981) predictions in Western Hudson Strait (Fig 2, frontal activity near Nottingham, Salisbury and Charles Islands). These areas are known biological hotspots where higher phytoplankton biomass is observed (Fig 3) and where large bird colonies are found. Beside these areas, our analysis also shows other regions with high frontal frequencies. One of the most important frontal region detected spans about $350 \mathrm{~km}$ on the southern shore of Baffin Island, from west of Big Island to near Cape Dorset. Its existence is likely not linked to tidal mixing since the Simpson-Hunter parameter indicates a stratified region (Drinkwater and Jones, 1987; Griffiths et al., 1981). As it follows the $200 \mathrm{~m}$ isobath, it may be the result of the cold Baffin Island current that enters the strait from the East and flows along the South edge of Baffin Island (Drinkwater, 1986; Straneo and Saucier, 2008). Another front is visible on the opposite side of the strait again following the $200 \mathrm{~m}$ isobath and may correspond to the northern edge of the Hudson Bay outflow. Field observations of the Hudson Strait inflow and outflow on a transect offshore on a section offshore from Big Island revealed that these are trapped within a distance of about $40 \mathrm{~km}$ from each coast (Straneo and Saucier, 2008). This distance roughly corresponds to the width of the sloping topography which is roughly comprised between the coast and a little offshore of the $200 \mathrm{~m}$ isobath. While the frontal region along Baffin Island does not appear to be linked with increased chlorophyll concentration, the region along Québec coast does (Fig 3). This may results from the different nature of both currents. While the inflow current on the north side of the channel is mostly barotropic and weakly stratified, the outflow is strongly baroclinic, with maximum velocity in the upper $\sim 100 \mathrm{~m}$ (Straneo and Saucier, 2008). The latter also carries nutrient-enriched water as the result of strong tidal mixing that occurs in the strait (Drinkwater and Harding, 2001).

At the eastern entrance of the strait, the most active tidal mixing area is located off the 
southern tip of Resolution Island. Our results show that fronts are more frequent a little southeast of the island tip. Advection may be responsible for the displacement of the surface signature of these fronts in the direction of the outflow, since the study of Griffiths et al. (1981) does not take into account the stabilizing effect of runoff into their tidal mixing model (Drinkwater and Jones, 1987; Garrett, Keeley, and Greenberg, 1978; Sutcliffe, Loucks, Drinkwater, and Coote, 1983). The entire region of eastern Hudson Strait is characterized by higher chl- $a$ concentrations with no obvious relation to the presence of that front.

In Ungava Bay, our analysis showed that the more frequent fronts are located along the southern and eastern coasts. The presence of rivers emptying large amounts of freshwater in this area (approximately $4500 \mathrm{~m}^{3} \mathrm{~s}^{-1}$, seen as high chlorophyll concentrations on Figure 3 ) is probably responsible for the generation of the observed fronts. One of the fronts predicted by Griffiths et al. (1981) in Ungava Bay has already been confirmed in the past by direct sampling (Taggart et al., 1989, red line in Figure 2). Our study shows that this front is likely small and less frequent compared to the surrounding other ones present in Ungava Bay. Despite this, it is of high biological significance as indicated by the presence of a large thick-billed mure colony on Akpatok Island.

Along the Labrador Shelf, a straight and sharp front appears close to the coast southeast of the Hudson Strait mouth. This front is likely the transition between coastal waters and the Labrador Shelf waters that flows on the shelf after their formation in the eastern Hudson Strait. The latter is a nutrient-rich mixture formed from Hudson Bay freshwater outflow, Baffin Island Current and West Greenland Current waters (Drinkwater and Harding, 2001; Dunbar, 1951; Sutcliffe et al., 1983). Despite its persistence, this front does not appear to be directly linked to high chl- $a$. The region of the northern Labrador shelf is however reputed to sustain high primary production throughout the summer (Drinkwater and Harding, 2001) and a bird colony is found at Seven Island Bay, close to that area.

Further south, the most frequent frontal activity on the inner shelf occurs near the mouth of Byron, Groswater and Sandwich Bays (Fig. 4). The presence of these fronts might be related to 
the inshore branch of the Labrador Current that flows shoreward of Hamilton and Nain Banks, and recirculates around them (Chapman and Beardsley, 1989; Colbourne, DeYoung, Narayanan, and Helbig, 1997; Wu, Tang, and Hannah, 2012). This likely causes a transition in temperature properties between the current and the coastal waters coming from the many fjords and bays in this area. Many important bird areas are located in this vicinity.

At the Shelf Break a persistent front is present offshore of the $1000 \mathrm{~m}$ isobath (Fig. 2 and 4). This front was briefly identified by Belkin et al. (2009) using a $9 \mathrm{~km}$ pixel resolution and is associated with the main branch of the Labrador Current. The high frequency of this front is a signature of the stability of the Labrador Current. The separation between this front and the inner branch of the Labrador Current described above consists in more complex flow patterns over the several banks in this area (Drinkwater and Harding, 2001; Fissel and Lemon, 1991).

\section{3.b Newfoundland Shelf}

Offshore circulation on the northern Newfoundland Shelf is a continuation of that on the Labrador Shelf resulting in a large occurrence of fronts along the $200 \mathrm{~m}$ isobath. Inshore, high frontal probability is found on the north shore of Newfoundland (Fig. 5), off the Northern Peninsula near the Strait of Belle-Isle. This front likely marks the limit between inner Labrador Current (LC) inflow into the Strait of Belle-Isle and the outflow from the Gulf of St. Lawrence. Other locations with higher frontal probabilities are located off different bays (Notre-Dame, Bonavista, Trinity and Conception). Those are probably a result of onshore excursion of the inner branch of cold LC flowing close to the shore, contrasting with coastal warmer waters in these bays during ice-free months. This area is characterized by relatively high chl- $a$ concentration near shore (Fig. 6) and the presence of large colonies of eiders, common mures, storm petrels and spawning sites of capelin (Davoren, 2007).

On the southern shore of Newfoundland there is a very high frequency of fronts $(\sim 8 \%)$ at the eastern side of the Laurentian Channel mouth (Fig. 5). A recent numerical study (Wu et al., 2012) reports that the LC extension that flows around the Avalon Peninsula also splits in 
two branches, one flowing west following the southern coast of Newfoundland and the other, not reported in literature before, flowing south into Halibut Channel to the mouth of the Laurentian Channel. The large amount of fronts detected in this area may be a result of the confluence of LC water flowing through Halibut Channel with the LC flowing along the Grand Banks towards the west and the outflow from the Gulf of St. Lawrence. Despite the large occurrence of fronts, this area does not appear to be characterized by a large concentration of chl- $a$ (Fig. 6).

Other high frontal probabilities are found south and west of Green Bank and on the southern side of the Avalon Channel. These can also be the results of local small-scale circulation not well established in the literature. Fronts with lower probabilities are also found in shallower areas close to the shore, south of the Avalon Peninsula and southwest of St. Pierre and Miquelon Islands. The very low frontal probability over the St. Pierre Bank and the Grand Banks may indicate high tidal mixing over these shallower areas. This important mixing can contribute to enhance the surface temperature contrast between the banks and the surrounding areas.

Another area where a large occurrence of fronts has been detected is along the continental shelf from East of the Grand Banks to Flemish Cap. This is an area of intense current convergence between the North Atlantic Current (NAC) and the LC generating the observed fronts (a complete description of the frontal zone near Flemish Cap can be found in Stein, 2007). A strong frontal activity is also present in the southern part of Flemish Pass, possibly because part of the Gulf Stream/NAC sometimes enters the pass from the south and meets the LC (e.g. Gil, Sánchez, Cerviño, and Garabana, 2004). These areas of frontal activity are all characterized by higher chl- $a$ contents than the oceanic region (Fig. 6).

\section{3.c Scotian Shelf and Gulf of Maine area}

Many areas having high frontal probabilities are located along the southwest tip of Nova-Scotia, Grand Manan Island and the upper reaches of the Bay of Fundy (Fig. 7), confirming previous observations that also showed these fronts to have a strong seasonal variability (Ullman and Cornillon, 1999). In this area, Garrett et al. (1978) and Loder and Greenberg (1986) highlighted 
regions where tidal mixing is strong enough to sustain well mixed water even in summertime when heat flux from the atmosphere is high. These regions all have nearby high frontal probabilities, in the transition zone between well-mixed (usually low probabilities) and stratified area. In addition to tidal mixing, Tee, Smith, and Lefaivre (1993) suggested that topographic upwelling can also generate fronts at the southwest tip of Nova-Scotia, off Cape Sable. All the regions mentioned above are reputed to be fish feeding and spawning areas (Sinclair and Iles, 1985). High frontal probabilities are also observed around Browns and Georges Banks, known for their enhanced tidal mixing and upwelling (e.g., Hannah, Shore, Loder, and Naimie, 2001; Mavor and Bisagni, 2001; Tee et al., 1993). This is consistent with the higher chl- $a$ concentrations observed in these regions where tidal mixing occurs (Fig. 8). Another high frontal probability area is located at the mouth of the Northeast Channel. These fronts are not associated with higher chl- $a$ concentrations and are likely due to convergent water masses, where the southwestward flow along the shelf edge enters the channel and meets the northwestward moving slope water (Hannah et al., 2001).

On the Scotian Shelf, the highest frontal probability occurs around Sable Island bank, probably as a result of tidal mixing combined with the anticyclonic gyre that exists around the bank (Hannah et al., 2001). Although less frequent, another frontal area corresponds to the location of the inner shelf current, shoreward of Lahave and Emerald Basins. This feature appears to be connected to the Sable Island bank frontal region. This observation supports the presence of a cross-shelf current off Cape Canso that was recently detected in a numerical study by Wu et al. (2012). Finally, some frontal activity is also visible in the Gully, possibly because of northward excursion of the slope current in this gap on the shelf break (Hannah et al., 2001). Of all these areas, only the fronts near the Southwest tip of Nova Scotia, at the Sable Island bank and along the cross-shelf front appear associated with higher chl- $a$ content (Fig. 8). This suggests that these fronts are related to tidal mixing while the others (e.g., the Gully and off Cape Canso) are related to current convergence. 


\section{3.d Gulf of St. Lawrence}

For convenience and in line with many regional studies (e.g., Bugden, 1981; Cyr, Bourgault, and Galbraith, 2011; Galbraith, 2006; Gilbert and Pettigrew, 1997), the Lower St. Lawrence Estuary (LSLE) is considered here part of the Gulf of St. Lawrence (GSL). Fronts and mesoscale dynamics are reputed to be frequent features in the GSL as a result of high buoyancy input from several rivers, combined with the importance of Coriolis effects in this large system (Ingram and El-Sabh, 1990; Koutitonsky and Bugden, 1991). Such processes are thought to greatly influence biological production and development and behavior of species at different life stage (e.g., Demers, Legendre, and Therriault, 1986; Le Fouest, Zakardjian, and Saucier, 2005; Legendre and Demers, 1984; Legendre, Demers, Therriault, and Boudreau, 1985). Mesoscale thermal fronts are also thought to be good proxies for food availability of whales, and thus closely related to their dynamical habitat (Doniol-Valcroze, Berteaux, Larouche, and Sears, 2007).

Highest probabilities of frontal structures in the Gulf of St. Lawrence (Fig. 9) appear in regions with low Simpson-Hunter parameter, i.e., where tidal mixing is likely at work (Lu, Thompson, and Wright, 2001, see their Figure 10a). These regions include the Strait of BelleIsle, Western Jacques-Cartier Strait, the North-Eastern tip of Nova-Scotia, the mouth of Baiedes-Chaleurs, several spots in Northumberland Strait and, to a lesser extent, both tips of the Magdalen Islands. High frontal activities are also present on the north shore of the Gulf and on the south shore of Anticosti Island. For these locations, fronts are likely the result of frequent upwellings due to dominant northwestern winds (Lacroix, 1987). The region of high frontal probability at the southern entrance of Strait of Belle-Isle is probably the result of the convergence between the LC water entering the Gulf from this strait and the West Newfoundland Current (recently identified in Bourgault, Cyr, Dumont, and Carter, 2014) that flows along the western coast of Newfoundland.

Another prominent frontal structure visible in Figure 9 corresponds to the separation between the Gaspé Current, that flows on the northern tip of Gaspésie Peninsula, and the An- 
ticosti Gyre, a cyclonic cell that is located north of the peninsula and west of the Anticosti Island. Frontal activity is also visible in the transition zone between the LSLE and the GSL near Pointe-des-Monts, where a southward flow separates both sub-regions and participates in channel-wide anticyclonic eddies that evolve on a synoptic time scale (Koutitonsky and Bugden, 1991; Larouche, Koutitonsky, Chanut, and El-Sabh, 1987). Relatively high frontal probabilities are seen throughout the St. Lawrence estuary region. These results from large-scale internal circulation features including cross-estuary currents and gyres (El-Sabh, 1979; Ingram and ElSabh, 1990; Larouche et al., 1987), and freshwater plumes extending from estuary's north shore rivers.

Finally, although not shown in Lu et al. (2001), the front present at the Head of the Laurentian Channel near Tadoussac is due to active tidal mixing that occurs on a sill that marks in upstream limit of the LSLE. The relatively cold water that results from this enhanced vertical mixing is a well known feature in the St. Lawrence (e.g., Gratton, Mertz, and Gagné, 1988; Ingram, 1976, 1979, 1983). A "cold anomaly", as it was referred in Gratton et al. (1988), can also emanate from this sill and travel up to $100 \mathrm{~km}$ on the south shore of the LSLE, but the sporadicity of such phenomenon makes it hard to detect from our 25 years timeseries. In winter (not shown here) the Head of the Laurentian Channel is sometimes referred as the Tadoussac polynya since water rarely freeze during the cold season as a result of upwelled water above the freezing point.

Some of the frontal features presented above are associated to higher chl- $a$ concentrations (Fig. 10). This is the case for the Magdalen Islands, the North-eastern tip of Nova Scotia, and to a lesser extent for the Jacques-Cartier Strait and southern Anticosti coast. The JacquesCartier Strait is known to support a community of marine mammals (Doniol-Valcroze et al., 2007; Kingsley and Reeves, 1998) and is located close to the Mingan Islands archipelago known to host a wide variety of marine birds. Chl- $a$ data for the estuary including the Gaspé current extension is unreliable due to high dissolved matter content of this estuary (Nieke, Reuter, Heuermann, Wang, M., and Therriault, 1997). In the Northumberland Strait, chl- $a$ data are 
contaminated by high concentrations of suspended matter (Ollerhead, 2005).

\section{3.e Hudson Bay and Foxe Basin}

Early thoughts from the pioneer work on the Hudson Bay system (Hachey, 1931; Huntsman, 1932; Vladykov, 1933) suggested that the region had a generally low biological production, driven it part by the short ice-free season and the highly stratified surface water (see also Bajkov, 1975). More recent work however suggest that the production is rather heterogeneous than weak, with higher phytoplankton and chlorophyll concentration near the coasts and in Hudson Strait (e.g. Ferland, Gosselin, and Starr, 2011; Harvey, Therriault, and Simard, 1997, 2001; Lapoussière, Michel, Gosselin, Poulin, Martin, and Tremblay, 2013; Roff and Legendre, 1986). Small scale mixing processes like tidal mixing, upwelling and river plumes may thus contribute significantly to the primary production of the Bay. These mixing processes are often accompanied by thermal front signatures.

The frequency of fronts for the Hudson Bay system is presented in Figure 11. Highest activity is nearly always at proximity of topographic features, with very low frontal probability in the central part of the bay where the water column is deeper than $100 \mathrm{~m}$. Belkin et al. (2009) only detected four major fronts in Hudson Bay: in northern Hudson Bay, east of the Belcher Islands, southern James Bay and in southwest Hudson Bay (see their Figure 63 in supplementary material). Our results confirm the presence of these fronts but the use of higher resolution SST imagery better highlights the complexity of the frontal patterns.

Tidal amplitudes are small in the center of the bay, increasing to $1.25 \mathrm{~m}$ on the western shore. The southeastern portion of the bay is also characterized by small tidal amplitudes $(<0.25 \mathrm{~m}$, Prinsenberg and Freeman, 1986). Tidal mixing is thus expected mostly along the western coasts. Tidal mixing fronts position predicted by Griffiths et al. (1981) and verified by Drinkwater and Jones (1987) generally agree with our observations for the southern tips of Southampton and Coats Islands and for the southern part of Hudson Bay and James Bay.

The frontal pattern around the Belcher Islands (Fig. 12) let us hypothesize that vertical 
mixing is also important in this area. This is supported by the recent study of Galbraith and Larouche (2011) that showed that this area has the second coldest surface water in the Hudson Bay system. Since no front were predicted by Griffiths et al. (1981) near these islands because the $\mathrm{M}_{2}$ tidal amplitude is lower than elsewhere on the coast (an amphidromic point is present north of the islands), it is not clear whether this colder water is the result of tidal or wind mixing.

The Belcher Islands region and its surroundings have been reported to have among the highest biological activity of the Hudson Bay system (Anderson and Roff, 1980; Anderson, Roff, and Gerkema, 1981; Harvey et al., 1997; Roff and Legendre, 1986). Indeed, higher chl-a levels around the Belcher Islands are consistent with the location of high frontal frequencies (Fig. 13). Many of these frontal areas are also associated to the presence of marine birds.

South of the Belcher Islands, the James Bay also has high frontal probabilities. Contrasting with the Belcher Islands, James Bay is the warmest part of Hudson Bay on average (Galbraith and Larouche, 2011). Together with tidal mixing, river runoff can also explain the high frontal frequency observed in James Bay. Surface water generally flow cyclonically around the Bay, getting diluted by freshwater from river discharge. Contamination by dissolved matter prevents accurate measurement of chl- $a$ in James Bay.

The long front present onshore of the $100 \mathrm{~m}$ isobath in the western Hudson Bay (Fig. 11, south of Chesterfield Inlet) may have a different origin than tidal mixing since the front is detached from the coast. Galbraith and Larouche (2011) reported this onshore region to be colder than the offshore, creating a persistent thermal front. They hypothesized that this is at least partly due to the advection of cold water from the northeastern Hudson Bay. What resembles a plume from the Inlet also creates a very persistent front that is entrained by the general cyclonic circulation of Hudson Bay. Besides water advection from the North, wind-driven upwellings may also be responsible for the increased presence of fronts along the western coast as winds are often blowing from the Southwest. The fact that there is almost no increase of chl- $a$ along that coast either indicates that the upwelling process is not intense enough or that the water brought to the surface is low in nutrient content (Fig. 13). Fronts observed along the 
southern Hudson Bay coast are associated to freshwater plumes from the Churchill and Nelson rivers with freshwater lying along the coast as it moves cyclonically towards the East.

West of the Hudson Strait, a long front stretches along the $100 \mathrm{~m}$ isobath and marks the division between the shallow Foxe Basin and the deeper Foxe Channel. In Foxe Basin (Fig. 14), persistent fronts coexist with regions of very low frontal probabilities (deep blue patch northeast of Foxe Peninsula). Front positions north of Prince Charles Island generally agree with the study of Griffiths et al. (1981). However, while no front were predicted by these authors between this island and the Foxe Peninsula, our observations show that the largest fronts in Foxe Basin are located in this area, over a submarine canyon of depth $>50 \mathrm{~m}$. This large front corresponds to a region of westward currents intensification that is part of a cyclonic cell that spans most of the southern Foxe Basin (Defossez, Saucier, Myers, Caya, and Dumais, 2012, their Figures 5e and 5f). Discrepancy between observed and predicted front locations by Griffiths et al. (1981) may also come from the poor bathymetry used by these authors.

Foxe Basin, except for its northwest part, is generally thought to have a well mixed water column and a very low biological activity since no nutrient-rich deep water is available to replenish the surface layer (Sibert, Zakardjian, Gosselin, Starr, Senneville, and LeClainche, 2011; Smith, Platt, Li, Horne, Harrison, Rao, and Irwin, 1985). In the northwest, higher biological production is sustained by nutrient-rich waters that flows through Fury and Hecla Strait. The numerous and persistent fronts in the eastern part of the basin probably originate from tidal mixing as indicated by the near freezing surface water observed in that area during the warmest week of the year (Galbraith and Larouche, 2011). Satellite chl- $a$ data shows a large patch of higher phytoplankton biomass located in southeastern Foxe Basin (Fig. 13) in the area where there is an increased frontal presence. This indicates that nutrient replenishment is possible probably through the presence of the deeper canyons. Discrepancy with numerical model results (Sibert et al., 2011) that show almost no phytoplankton biomass in that area probably results from insufficient spatial resolution of the model $(10 \mathrm{~km})$. Considering the relatively low phytoplankton biomass generally observed in Foxe Basin, this area may well be a local biological hot 
spot as indicated by the large colonies of marine birds on Prince Charles Islands and adjacent Baffin Island coast. This area is also known to be important for various marine mammals.

\section{3.f Baffin Bay}

Baffin Bay is a large abyssal plain connected to the Arctic Ocean through Smith, Jones and Lancaster Sounds, and to the Atlantic Ocean through Davis Strait. Very few studies discuss the presence of fronts in Baffin Bay. The remoteness and the presence of ice for most of the year are factors explaining this lack of information. Muench (1990) discussed the presence of front east and west of Greenland, but the study was limited to the Labrador sea, without entering into Baffin Bay. He noted however the importance of fronts for vertical and horizontal fluxes of dissolved material such as nutrients. He also noted that frontal systems in polar seas often coincide with the marginal ice zone.

Figure 15 shows the frequency of fronts for Baffin Bay. The area with the highest frontal frequency is located in Melville Bay. This front was identified by Belkin et al. (2009), but without indication of its much higher frontal probability compared to the rest of the western Greenland large marine ecosystem (see their Figure 18 in supplementary material). According to Belkin et al. (2009), the Melville Bay front is part of the Mid-Shelf Front (MSF) running along the West Greenland coast. Our results show that the MSF is not well detected by the variable-window approach probably as a consequence of its small surface temperature gradients. Only some areas closer to the coast near topographic features such as islands and fjords do show higher frontal probabilities. Succession of calving glaciers on more than $400 \mathrm{~km}$ of the coastline in this area (e.g. Van As, 2011) may modify water properties and partly explains frontal characteristics observed near the coast. This area along the west Greenland coast is characterized by relatively high chl- $a$ concentrations up to $74^{\circ} \mathrm{N}$ (Fig. 16).

Quite surprisingly, even though Melville Bay is a well-known area since the mid-19th century for whales concentration, it does not have high chl- $a$ concentrations. This indicates that the Melville Bay fronts are not generating nutrient replenishment of the surface layer. It is probable 
that the nature of these fronts is more related to surface density gradients generated by the many glaciers in the area than to upwelling process. Very few oceanographic measurements were made in that area but there are some indications that Melville Bay surface coastal waters are fresher than further offshore, generating an important baroclinic density front that also has a surface temperature signature (Lobb, Weaver, Carmack, and Ingram, 2003; Valeur, Hansen, Hansen, Rasmussen, and Thingvad, 1996).

Further offshore, there is a higher frontal frequency located above the $1000 \mathrm{~m}$ isobath and corresponding to the West Greenland Current Front (WGCF, Belkin et al., 2009). Some onshore excursions that coincide with the presence of cross-shelf channels are also observed. On the western side of Baffin Bay, the highest frontal frequencies are located at the mouth of Lancaster Sound. High frontal probabilities are found on both sides of the sound above the $500 \mathrm{~m}$ isobath. Direct observations (current meters) and tracked icebergs and drifters (de Lange Boom, Macneill, and Buckley, 1982; Fissel, Lemon, and Birch, 1982; Marko, Birch, and Wilson, 1982) have shown that the southward arctic flow from Smith and Jones Sounds makes significant excursion into the eastern Lancaster Sound. Frontal structure of this current was already observed in CTD transects (Fissel et al., 1982). Numerical simulations suggest that the inflow (mostly a barotropic advection of salty waters from the Baffin Current) enters the sound from its northern side and recirculates cyclonically in the eastern part before exiting on the south side, where the outflow (strongly baroclinic with maximum current velocity over the upper $100 \mathrm{~m}$ ) also carries fresher runoff from the sound (Wang, Myers, Hu, and Bush, 2012).

The high frontal probabilities observed off the mouth of Lancaster Sound do not have a clear generation mechanism. Very few measurements are available from that area, but the study of Fissel et al. (1982) indicate that area to be characterized by small and variable currents. This is confirmed by results from numerical experiments (Wang et al., 2012). This area is however associated to higher levels of chl- $a$ (Fig. 16) suggesting the presence of a sustained phytoplankton biomass possibly through a nutrient regeneration mechanism. The entire area near the entrance of Lancaster Sound is also known as a hot spot for marine birds (Wong, Gjerdrum, Morgan, and 
Mallory, 2014) and marine mammals (Davis and Koski, 1980; Davis, Richardson, Johnson, and Renaud, 1978).

Along the $1000 \mathrm{~m}$ isobath on the west side of the Baffin Bay, the front that one could expect with the presence of the Baffin Island Current that flows south (Tang, Ross, Yao, Petrie, DeTracey, and Dunlap, 2004; Wu et al., 2012) is not clearly visible until it passes Davis Strait. At this point, the current intensifies and meets the northernmost extension of the WGC, generating a long front, extending from Davis Strait to the mouth of Hudson Strait, above the $500 \mathrm{~m}$ isobath (Wu et al., 2012). The area where the two currents meet has been identified as a high primary production region (Tremblay, Robert, Varela, Lovejoy, Darnis, Nelson, and Sastri, 2012)

Northern Baffin Bay is the host of the North Water (NOW) polynya, one of the largest and most biologically productive polynyas in the world (see Barber, Marsden, Minnett, Ingram, and Fortier, 2001; Deming, Fortier, and Fukuchi, 2002, and articles therein for an exhaustive study of the polynya). Ingram, Bâcle, Barber, Gratton, and Melling (2002) defined the spatial extent of the polynya from Smith Sound, where constriction of ice in Nares Strait is responsible for the opening of the polynya (e.g. Dumont, Gratton, and Arbetter, 2009; Melling, Gratton, and Ingram, 2001) to $76^{\circ} \mathrm{N}$, an arbitrary limit. The entire polynya area is characterized by high satellite-derived chl- $a$ concentrations confirming the in situ measurements done during the Northwater Polynya project (Mei, Legendre, Gratton, Tremblay, LeBlanc, Mundy, Klein, Gosselin, Larouche, Papakyriakou, Lovejoy, and von Quillfeldt, 2002). Within the NOW, some high frontal probabilities areas are found near the Carey Islands, out of the Jones Sound and southeast of Smith Sound near Qaanaaq. A very large colony of marine birds is located on Coburg Island at the entrance of Jones Sound.

\section{3.g Northeast Pacific Ocean}

Frontal probabilities for the Northeast Pacific are presented in Figure 17. An extensive study of thermal fronts in the Pacific ocean and its marginal seas have already been published by Belkin and Cornillon (2003). Major large scale features highlighted in our study have thus already been 
described. To avoid redundancy, we will limit ourselves to new features found in our dataset that emerged from the greater resolution $(1.1 \mathrm{~km}$ vs $9.28 \mathrm{~km})$ and the different algorithm (VW-SIED) used.

Possibly the most striking difference with the Belkin and Cornillon (2003) study is the relative absence of distinct front for most of the open water, i.e., far from the coast (Fig.17). This difference illustrates how the spatial resolution and the algorithm used in our study affect front detection by selecting fronts where SST gradients are stronger and at a smaller scale.

Figure 18 present frontal probabilities for the Gulf of Alaska. A major oceanographic circulation features of the Gulf of Alaska is the Alaska Current (see Reed and Shumacher, 1986, for an extensive review of the physical oceanography of the Gulf of Alaska). It is a wide current $(\sim 400 \mathrm{~km})$ that flows along the western Alaska coast from Queen Charlotte Islands to the head of the Gulf (the northernmost part of the Gulf). Although Belkin and Cornillon (2003) found that the Self-Slope Front (SSF) is associated with this current, this front does not clearly showup in our 25-years high-resolution dataset (Fig. 18). It is possible that the meandering, seasonal evolution and the presence of eddies (Belkin and Cornillon, 2003; Crawford, Brickley, Peterson, and Thomas, 2005; Ueno, Sato, Freeland, Crawford, Onishi, Oka, and Suga, 2009; Whitney, Crawford, and Harrison, 2005) scatters the signal at $1.1 \mathrm{~km}$ resolution. Highest frontal probabilities are found in the northern Gulf of Alaska, between Cross and Prince William Sounds, and are more or less constrained between the coast and the $100 \mathrm{~m}$ isobath. Coastal runoff from the Copper and Alsek rivers and the presence of inlets, bays and nearby on-land glaciers and ice fields may be partly responsible for these high frontal probabilities.

Climatological chlorophyll data show higher concentrations along the coast (Fig. 19), consistent with a previous study (Brickley and Thomas, 2004). There is however a strong seasonality of chlorophyll that is influenced by reduced downwelling-favorable winds in summer that lower SST along the coast (Waite and Mueter, 2013). Both SST and chlorophyll variables have been found to be related, although high chl- $a$ concentration measurements may also be influenced by high turbidity and freshwater in this area (Stabeno, Bond, Hermann, Kachel, Mordy, and Overland, 
2004). Except along its western coast, the strong chlorophyll concentrations observed within the Alexander archipelago are not associated to higher frontal probabilities. Further south, in Hecate Strait, high frontal probabilities are found along the northern Queen Charlotte Islands, coincident with what is predicted by the Simpson-Hunter stratification parameter in this area (Perry et al., 1983). Tidal mixing over the shallow regions of the strait is the likely generation mechanism responsible for these fronts that are linked to high chlorophyll (Fig. 21) and nutrient and plankton concentrations (Perry et al., 1983). Humpback whales are also present in this area (Dalla Rosa, Ford, and Trites, 2012).

High frontal probabilities are also observed west of Vancouver Island (Fig. 20). These are probably driven by the seasonal wind-driven upwellings (Freeland and Denman, 1982) and are associated with very high chlorophyll concentrations (Fig. 21). The highest frontal probabilities near Vancouver Island are however found at the Juan de Fuca Strait entrance and in the Strait of Georgia. The former is the location of a seasonal eddy (Freeland and Denman, 1982) leading to cold surface waters. Strong tidal mixing in the strait also leads to enhanced nutrients in the surface layer. This area is known for the presence of birds, fish and whales (Dalla Rosa et al., 2012; Healey, Thomson, and Morris, 1990; Vermeer, Butler, and Morgan, 1992) and a strong association was found between many seabird species and temperature gradients in the coastal zone along a transect extending off Juan de Fuca Strait (O'Hara, Morgan, and Sydeman, 2006). In the Strait of Georgia, the high frontal probability observed is likely resulting from the strong freshwater outflow from the Fraser river $\left(3800 \mathrm{~m}^{3} \mathrm{~s}^{-1}\right)$. The presence of large amounts of dissolved and suspended matter in that area makes comparison with climatological chlorophyll maps difficult. The high frontal probability observed along the Washington coast results from the presence of the California Current System. The coastal upwelling typical of southward flowing eastern boundary currents produces a strong thermal contrast between warm offshore and cold inshore waters creating a permanent front. This is a well known oceanographic feature previously discussed in Belkin (2002). 


\section{Conclusion}

Using 25 years of satellite data, the results showed the location of fronts over Canadian coastal waters. Many of these fronts have been detected for the first time due to the use of the increased spatial resolution imagery combined with the variable window-size detection algorithm. The results showed that many fronts are associated to increased biological activity (chlorophyll concentration). However, some very prominent fronts showed no signature on chlorophyll concentration images. This shows that the front generation mechanism is important in determining the role of fronts on the ecosystems. Because fronts generated by processes such as upwellings and tidal mixing inject nutrients in the surface layer, they may be more efficient than density driven fronts in sustaining primary production and the upper trophic levels of the marine food chain.

The aim of this study was to provide a reference document which can be consulted in preparation to physical and biochemical studies in Canadian coastal waters area, or to interpret results of previous campaigns with a broader perspective. Results of this study can be also used for validating numerical modeling studies. For example, many fronts described in this paper are likely corresponding to currents (e.g. in the Halibut Channel and off Cape Canso) or gyre (e.g. in Foxe Basin) that were only identified in numerical results.

Finally, the datasets used in this study is enormous and can still be exploited. In particular, the 25-year timeseries can be used to study the temporal evolution of the fronts in a context of environmental changes. Also, the daily images of fronts allow a tracking of their seasonal evolution. These studies could be realized at a broad scale (e.g. Canadian waters) or in specific subregions.

\section{Acknowledgments}

This work was made possible by a grant from the Canadian Space Agency and is a contribution to the scientific program of Québec-Océan. Thanks to Alexandre Livernoche, Jonathan 
Graveline, Guillaume Desbiens, Julien Laliberté and Audrey Patry-Quintin for their help with data processing. We also acknowledge the helpful comments from Dr. Igor M. Belkin and one anonymous reviewer.

\section{References}

Anderson, J.T. and Roff, J.C., 1980. Seston ecology of the surface waters of Hudson Bay, Canadian Journal Fisheries Aquatic Sciences, 37, 2242-2253.

Anderson, J.T., Roff, J.C., and Gerkema, T., 1981. The diatoms and dinoflagellates of Hudson Bay, Canadian journal of Botany, 59, 1793-1810.

Bajkov, A., 1975. Is Hudson Bay a Desert Sea?, Manuscript report, Manitoba Mines, Resources, Environmental Management, Research Branch.

Barber, D., Marsden, R., Minnett, P., Ingram, R.G., and Fortier, L., 2001. Physical processes within the North Water (NOW) polynya, Atmosphere-Ocean, 39 (3), 163-166.

Belkin, I.M., 2002. New challenge: ocean fronts, Journal of Marine Systems, 37 (2002), 1-2.

Belkin, I.M. and Cornillon, P., 2003. SST fronts of the Pacific coastal and marginal seas, Pacific Oceanography, 1 (2), 90-113.

Belkin, I.M., Cornillon, P., and Ullman, D., 2001. Ocean fronts around Alaska from satellite SST data, in: American Meteorological Society 7th Conference on the Polar Meteorology and Oceanography, Hyannis, MA, USA.

Belkin, I.M., Cornillon, P.C., and Sherman, K., 2009. Fronts in Large Marine Ecosystems, Progress in Oceanography, 81 (1-4), 223-236.

Bisagni, J.J., Kim, H.S., and Chaudhuri, A., 2009. Interannual variability of the shelf-slope front position between $75^{\circ}$ and $50^{\circ} \mathrm{W}$, Journal of Marine Systems, 78 (3), 337-350.

Bourgault, D., Cyr, F., Dumont, D., and Carter, A., 2014. Numerical simulations of the spread of floating passive tracer released at the Old Harry prospect, Environmental Research Letters, $9(5), 14$ pp.

Brickley, P.J. and Thomas, A.C., 2004. Satellite-measured seasonal and inter-annual chlorophyll 
variability in the Northeast Pacific and coastal Gulf of Alaska, Deep Sea Research Part II: Topical Studies in Oceanography, 51 (1-3), 229-245.

Bugden, G.L., 1981. Salt and heat budgets for the Gulf of St. Lawrence, Canadian Journal of Fisheries and Aquatic Sciences, 38 (9), 1153-1167.

Canadian Wildlife Service, 2012. Important areas for birds in Nunavut, Environment Canada, CW66-302/2, 81 pp.

Cayula, J.F. and Cornillon, P.C., 1992. Edge detection algorithm for SST images, Journal of Atmospheric and Oceanic Technology, 9, 67-80.

Chapman, D.C. and Beardsley, R.C., 1989. On the origin of Shelf Water in the Middle Atlantic Bight, Journal of Physical Oceanography, 19, 384-391.

Colbourne, E., DeYoung, B., Narayanan, S., and Helbig, J., 1997. Comparison of hydrography and circulation on the Newfoundland Shelf during 1990-1993 with the long-term mean, Canadian Journal of Fisheries and Aquatic Sciences, 54 (S1), 68-80.

Crawford, W.R., Brickley, P.J., Peterson, T.D., and Thomas, A.C., 2005. Impact of Haida Eddies on chlorophyll distribution in the Eastern Gulf of Alaska, Deep Sea Research Part II: Topical Studies in Oceanography, 52 (7-8), 975-989.

Cyr, F., Bourgault, D., and Galbraith, P.S., 2011. Interior versus boundary mixing of a cold intermediate layer, Journal of Geophysical Research, 116 (C12029), 1-12.

Dalla Rosa, L., Ford, J.K., and Trites, A.W., 2012. Distribution and relative abundance of humpback whales in relation to environmental variables in coastal British Columbia and adjacent waters, Continental Shelf Research, 36, 89-104.

Davis, R.A. and Koski, W.R., 1980. Recent observations of the bowhead whale in the Eastern Canadian High Arctic, in: Thirtieth report of the International Whaling Commission, Cambridge: The International Whaling Commission, 439-444.

Davis, R.A., Richardson, J., Johnson, S.R., and Renaud, W.E., 1978. Status of the Lancaster Sound narwhal population in 1976, in: Twenty-eighth report of the International Whaling Commission, Cambridge: The International Whaling Commission, 205-215. 
Davoren, G.K., 2007. Effects of gill-net fishing on marine birds in a biological hotspot in the northwest Atlantic., Conservation biology : the journal of the Society for Conservation Biology, $21(4), 1032-45$

de Lange Boom, B.R., Macneill, M.R., and Buckley, J.R., 1982. Iceberg motion in Lancaster Sound and Northwest Baffin Bay, summer 1978, Arctic, 35 (1), 219-233.

Defossez, M., Saucier, F.J., Myers, P., Caya, D., and Dumais, J.F., 2012. Comparing Winter and Summer Simulated Estuarine Circulations in Foxe Basin, Canada, Atmosphere-Ocean, $50(3), 386-401$.

Demers, S., Legendre, L., and Therriault, J.C., 1986. Phytoplankton responses to vertical tidal mixing, in: J. Bowman, M. Yentsch, and W.T. Peterson, eds., Tidal mixing and plankton dynamics, Berlin Heidelberg: Springer-Verlag, 1-40.

Deming, J.W., Fortier, L., and Fukuchi, M., 2002. The International North Water Polynya Study (NOW): a brief overview, Deep Sea Research Part II: Topical Studies in Oceanography, 49, $4887-4892$.

Diehl, S.F., Budd, J.W., Ullman, D., and Cayula, J.F., 2002. Geographic window sizes applied to remote sensing sea surface temperature front detection, Journal of Atmospheric and Oceanic Technology, 19, 1105-1113.

Doniol-Valcroze, T., Berteaux, D., Larouche, P., and Sears, R., 2007. Influence of thermal fronts on habitat selection by four rorqual whale species in the Gulf of St. Lawrence, Marine Ecology Progress Series, 335, 207-216.

Drinkwater, K.F., 1986. Physical oceanography of Hudson Strait and Ungava Bay, in: I.P. Martini, ed., Canadian Inland Seas, New York: Elsevier, vol. 44, chap. 13, 237-264.

Drinkwater, K.F. and Harding, G., 2001. Effects of the Hudson Strait outflow on the biology of the Labrador Shelf, Canadian Journal of Fisheries and Aquatic Sciences, 58 (1), 171-184.

Drinkwater, K.F. and Jones, E., 1987. Density stratification, nutrient and chlorophyll distributions in the Hudson Strait region during summer and their relation to tidal mixing, Continental Shelf Research, 7 (6), 599-607. 
Dumont, D., Gratton, Y., and Arbetter, T.E., 2009. Modeling the dynamics of the North Water polynya ice bridge, Journal of Physical Oceanography, 39 (6), 1448-1461.

Dunbar, M.J., 1951. Eastern Arctic Waters, Tech. Rep. Bulletin No. 88, Fisheries Research Board of Canada, Ottawa.

El-Sabh, M.I., 1979. The Lower St. Lawrence Estuary as a physical oceanographic system, Le Naturaliste Canadien, 106, 55-73.

Ferland, J., Gosselin, M., and Starr, M., 2011. Environmental control of summer primary production in the Hudson Bay system: The role of stratification, Journal of Marine Systems, $88(3), 385-400$.

Fissel, D.B., Lemon, D.D., and Birch, J.R., 1982. Major features of the summer near-surface circulation of Western Baffin Bay, 1978 and 1979, Arctic, 35 (1), 180-200.

Fissel, D.B. and Lemon, D.O., 1991. Analysis of Physical Oceanographic Data from the Labrador Shelf, Summer 1980, Canadian Contractor Report of Hydrography and Ocean Sciences, 39, xviii $+136 \mathrm{pp}$.

Freeland, H. and Denman, K.L., 1982. A topographically controlled upwelling centre off southern Vancouver Island, Journal of Marine Research, 40 (4), 1069-1093.

Galbraith, P.S., 2006. Winter water masses in the Gulf of St. Lawrence, Journal of Geophysical Research, 111 (C6), 1-23.

Galbraith, P.S. and Larouche, P., 2011. Sea-surface temperature in Hudson Bay and Hudson Strait in relation to air temperature and ice cover breakup, 1985-2009, Journal of Marine Systems, 87 (1), 66-78.

Garrett, C.J.R., Keeley, J.R., and Greenberg, D.A., 1978. Tidal mixing versus thermal stratification in the Bay of Fundy and Gulf of Maine, Atmosphere-Ocean, 16 (4), 403-423.

Gil, J., Sánchez, R., Cerviño, S., and Garabana, D., 2004. Geostrophic circulation and heat flux across the Flemish Cap, 1988-2000, Journal of Northwest Atlantic Fishery Science, 34, 63-83.

Gilbert, D. and Pettigrew, B., 1997. Interannual variability (1948-1994) of the CIL core temperature in the Gulf of St. Lawrence, Canadian Journal of Fisheries and Aquatic Sciences, 
54 (S1), 57-67.

Gratton, Y., Mertz, G., and Gagné, J.A., 1988. Satellite observations of tidal upwelling and mixing in the St. Lawrence Estuary, Journal of Geophysical Research, 93 (C6), 6947-6954.

Griffiths, D., Pingree, R., and Sinclair, M., 1981. Summer tidal fronts in the near-arctic regions of Foxe Basin and Hudson Bay, Deep Sea Research Part A. Oceanographic Research Papers, $28(8), 865-873$.

Hachey, H.B., 1931. Biological and oceanographic conditions in Hudson Bay 6. The general hydrography and hydrodynamics of the waters of the Hudson Bay region, Contributions to Canadian Biology and Fisheries, 7 (1), 91-118.

Hannah, C., Shore, J.A., Loder, J.W., and Naimie, C.E., 2001. Seasonal circulation on the Western and Central Scotian Shelf, Journal of Physical Oceanography, 31, 591-615.

Harvey, M., Therriault, J.C., and Simard, N., 1997. Late-summer distribution of phytoplankton in relation to water mass characteristics in Hudson Bay and Hudson Strait (Canada), Canadian Journal of Fisheries and Aquatic Sciences, 54 (8), 1937-1952.

Harvey, M., Therriault, J.C., and Simard, N., 2001. Hydrodynamic control of late summer species composition and abundance of zooplankton in Hudson Bay and Hudson Strait (Canada), Journal of Plankton Research, 23 (5), 481-496.

Healey, M.C., Thomson, R.E., and Morris, J.F.T., 1990. Distribution of commercial troll fishing vessels off southwest Vancouver Island in relation to fishing success and oceanic water properties and circulation, Canadian Journal of Fisheries and Aquatic Sciences, 47 (10), 1846-1864.

Huntsman, A.G., 1932. Biological and oceanographic conditions in Hudson Bay 1. Hudson Bay and the determination of fisheries, Contributions to Canadian Biology and Fisheries, 6 (1), $455-462$.

Ingram, R.G., 1976. Characteristics of a tide-induced estuarine front, Journal of Geophysical Research, 81 (12), 1951-1959.

Ingram, R.G., 1979. Water mass modification in the St. Lawrence Estuary, Le Naturaliste Canadien, 106, 45-54. 
Ingram, R.G., 1983. Vertical mixing at the head of the Laurentian Channel, Estuarine, Coastal and Shelf Science, 16 (3), 333-338.

Ingram, R.G., Bâcle, J., Barber, D.G., Gratton, Y., and Melling, H., 2002. An overview of physical processes in the North Water, Deep Sea Research Part II: Topical Studies in Oceanography, $49(22-23), 4893-4906$.

Ingram, R.G. and El-Sabh, M.I., 1990. Fronts and mesoscale features in the St. Lawrence Estuary, in: M.I. El Sabh and N. Silverberg, eds., Oceanography of a Large-Scale Estuarine System: The St. Lawrence, New York: Springer-Verlag, 71-93.

Jardine, I.D., Thomson, K.A., Foreman, M.G., and Leblond, P.H., 1993. Remote sensing of coastal sea-surface features off Northern British Columbia, Remote Sensing of Environment, $84,73-84$.

Kahru, M., Di Lorenzo, E., Manzano-Sarabia, M., and Mitchell, B.G., 2012. Spatial and temporal statistics of sea surface temperature and chlorophyll fronts in the California Current, Journal of Plankton Research, 34 (9), 749-760.

Kingsley, M. and Reeves, R., 1998. Aerial surveys of cetaceans in the Gulf of St. Lawrence in 1995 and 1996, Canadian Journal of Zoology, 76 (8), 1529-1550.

Koutitonsky, V.G. and Bugden, G.L., 1991. The physical oceanography of the Gulf of St. Lawrence: a review with emphasis on the synoptic variability of the motion, in: J.C. Therriault, ed., The Gulf of St. Lawrence: small ocean or big estuary?, Canadian Special Publication of Fisheries and Aquatic Sciences 113, vol. 113, 57-90.

Lacroix, J., 1987. Étude descriptive de la variabilité spatio-temporelle des phénomènes physiques de surface de l'estuaire maritime et la partie nord-ouest du golfe du St. Laurent à l'aide d'images thermiques du satellite NOAA-7, Master's thesis, Université du Québec à Rimouski. Lapoussière, A., Michel, C., Gosselin, M., Poulin, M., Martin, J., and Tremblay, J.E., 2013. Primary production and sinking export during fall in the Hudson Bay system, Canada, Continental Shelf Research, 52, 62-72.

Larouche, P., Koutitonsky, V.G., Chanut, J.P., and El-Sabh, M.I., 1987. Lateral stratification 
balance at the Matane transect in the Lower Saint Lawrence Estuary, Estuarine, Coastal and Shelf Science, 24, 859-871.

Lavoie, A., Bonn, F., Dubois, J.M.M., and El-Sabh, M.I., 1985. Structure thermique et variabilité du courant de surface de l'estuaire maritime du Saint-Laurent à l'aide d'images du satellite HCMM, Canadian Journal of Remote Sensing, 11, 70-84.

Le Fouest, V., Zakardjian, B.A., and Saucier, F.J., 2005. Seasonal versus synoptic variability in planktonic production in a high-latitude marginal sea: The Gulf of St. Lawrence (Canada), Journal of Geophysical Research, 110 (C9), 1-21.

Legeckis, R., Brown, C.W., and Chang, P.S., 2002. Geostationary satellites reveal motions of ocean surface fronts, Journal of Marine Systems, 37 (1-3), 3-15.

Legendre, L. and Demers, S., 1984. Towards dynamic biological oceanography and limnology, Canadian Journal Fisheries Aquatic Sciences, 41, 2-19.

Legendre, L., Demers, S., Therriault, J.C., and Boudreau, C.A., 1985. Tidal variations in the photosynthesis of estuarine phytoplankton isolated in a tank, Marine Biology, 88, 301-309.

Lobb, J., Weaver, A.J., Carmack, E.C., and Ingram, R.G., 2003. Structure and mixing across an Arctic/Atlantic front in northern Baffin Bay, Geophysical Research Letters, 30 (16).

Loder, J.W. and Greenberg, D.A., 1986. Predicted positions of tidal fronts in the Gulf of Maine region, Continental Shelf Research, 6 (3), 397-414.

Lu, Y., Thompson, K.R., and Wright, D.G., 2001. Tidal currents and mi×ing in the Gulf of St. Lawrence: an application of the incremental approach to data assimilation, Canadian Journal of Fisheries and Aquatic Sciences, 58 (4), 723-735.

Marko, J.R., Birch, J.R., and Wilson, M.A., 1982. A Study of Long-Term Satellite-Tracked Iceberg Drifts in Baffin Bay, Arctic, 35 (1), 234-240.

Mavor, T.P. and Bisagni, J.J., 2001. Seasonal variability of sea-surface temperature fronts on Georges Bank, Deep Sea Research Part II, 48, 215-243.

Mei, Z.P., Legendre, L., Gratton, Y., Tremblay, J.E., LeBlanc, B., Mundy, C., Klein, B., Gosselin, M., Larouche, P., Papakyriakou, T., Lovejoy, C., and von Quillfeldt, C., 2002. Physical control 

of spring-summer phytoplankton dynamics in the North Water, April-July 1998, Deep Sea Research Part II: Topical Studies in Oceanography, 49 (22-23), 4959-4982.

Melling, H., Gratton, Y., and Ingram, R.G., 2001. Ocean circulation within the North Water polynya of Baffin Bay, Atmosphere-Ocean, 39 (3), 301-325.

Muench, R.D., 1990. Mesoscale phenomena in the polar ocean, in: W.O. Smith Jr., ed., Polar oceanography part A: physical science, San Diego, CA: Academic Press, 223-285.

Nieke, B., Reuter, R., Heuermann, R., Wang, H., M., B., and Therriault, J.C., 1997. Light absorption and fluorescence properties of chromophoric dissolved organic matter (CDOM), in the St. Lawrence Estuary (Case 2 waters), Continental Shelf Research, 17 (3), 235-252.

Nieto, K., Demarcq, H., and McClatchie, S., 2012. Mesoscale frontal structures in the Canary Upwelling System: New front and filament detection algorithms applied to spatial and temporal patterns, Remote Sensing of Environment, 123, 339-346.

Ollerhead, J., 2005. Measurements of inorganic suspended sediment concentration in the Northumberland strait in October of 2005, Tech. rep., Mount Allison University, Sackville, Canada.

O'Hara, P., Morgan, K., and Sydeman, W., 2006. Primary producer and seabird associations with AVHRR-derived sea surface temperatures and gradients in the southeastern Gulf of Alaska, Deep Sea Research Part II: Topical Studies in Oceanography, 53 (3-4), 359-369.

Perry, R.I., Dilke, B.R., and Parsons, T.R., 1983. Tidal mixing and summer plankton distributions in Hecate Strait, British Columbia, Canadian Journal Fisheries Aquatic Sciences, 40 (57 147).

Pettigrew, B., Larouche, P., and Gilbert, D., 2011. Validation des images composites des température de surface produites au laboratoire de télédétection de l'institut MauriceLamontagne, Rapport technique canadien sur l'hydrographie et les sciences océaniques, 270, viii $+31 \mathrm{p}$.

Prinsenberg, S.J. and Freeman, N.G., 1986. Tidal heights and currents in Hudson Bay and James Bay, in: I.P. Martini, ed., Canadian Inland Seas, New York: Elsevier, Elsevier Oceanography 
Series, vol. 44, 205-216.

Reed, R.K. and Shumacher, J.D., 1986. Physical oceanography, in: D.W. Hood and S.T. Zimmerman, eds., The Gulf of Alaska, Physical environment and biological resources, U.S. Dept. of Commerce, National Oceanic and Atmospheric Administration, National Ocean Service, Office of Oceanography and Marine Assessment, Ocean Assessments Division, Alaska Office, chap. 3, 57-75.

Roff, J.C. and Legendre, L., 1986. Physico-chemical and biological oceanography of Hudson Bay, in: I.P. Martini, ed., Canadian Inland Seas, New York: Elsevier, Elsevier Oceanography Series, vol. $44,265-292$.

Sherman, K., 1990. Productivity, perturbations, and options for biomass yields in large marine ecosystems, in: K. Sherman, L.M. Alexander, and B.D. Gold, eds., Large marine ecosystems: patterns, processes and yields, Washington D.C.: American Association for the Advancement of Science, 206-219.

Sherman, K., 2005. The large marine ecosystem approach for assessment and management of ocean coastal waters, in: T. Hennessey and J. Sutinen, eds., Sustaining the Large Marine Ecosystems: The Human Dimension, Amsterdam: Elsevier, 3-16.

Sibert, V., Zakardjian, B., Gosselin, M., Starr, M., Senneville, S., and LeClainche, Y., 2011. 3D bio-physical model of the sympagic and planktonic productions in the Hudson Bay system, Journal of Marine Systems, 88 (3), 401-422.

Simpson, J.H. and Hunter, J.R., 1974. Fronts in the Irish Sea, Nature, 250, 404-406.

Sinclair, M. and Iles, T.D., 1985. Atlantic Herring (Clupea harengus) distributions in the Gulf of Maine - Scotian Shelf area in relation to oceanographic features, Canadian Journal Fisheries Aquatic Sciences, 42, 880-887.

Smith, J.C., Platt, T., Li, W.K.W., Horne, E.P.W., Harrison, W.G., Rao, D.V.S., and Irwin, B.D., 1985. Arctic marine photoautotrophic picoplankton, Marine Ecology Progress Series, $20,207-220$.

Sommerkorn, C.P., 2012. RACER: Rapid Assessment of Circum-arctic Ecosystem Resilience, 
Ottawa, Canada: WWF Global Arctic Programme, 2nd ed.

Stabeno, P., Bond, N., Hermann, A., Kachel, N., Mordy, C., and Overland, J., 2004. Meteorology and oceanography of the Northern Gulf of Alaska, Continental Shelf Research, 24 (7-8), 859897.

Stein, M., 2007. Oceanography of the Flemish Cap and adjacent waters, Journal of Northwest Atlantic Fishery Science, 37 (February), 135-146.

Straneo, F. and Saucier, F., 2008. The outflow from Hudson Strait and its contribution to the Labrador Current, Deep Sea Research Part I: Oceanographic Research Papers, 55 (8), 926-946.

Sutcliffe, W.H., Loucks, R.H., Drinkwater, K.F., and Coote, A.R., 1983. Nutrient flux onto the Labrador Shelf from Hudson Strait and its biological consequences, Canadian Journal of Fisheries and Aquatic Sciences, 40, 1692-1701.

Taggart, C.T., Drinkwater, K.F., Frank, K.T., McRuer, J., and Larouche, P., 1989. Larval fish, zooplankton community structure, and physical dynamics at a tidal front, Rapports et Procesverbaux des Réunions. Conseil International pour l'Éxploration de la Mer, 191, 184-194.

Tang, C.C., Ross, C.K., Yao, T., Petrie, B., DeTracey, B.M., and Dunlap, E., 2004. The circulation, water masses and sea-ice of Baffin Bay, Progress in Oceanography, 63 (4), 183-228.

Tee, K.T., Smith, P.C., and Lefaivre, D., 1993. Topographic upwelling off Southwest Nova Scotia, Journal of Physical Oceanography, 23, 1703-1726.

Tremblay, J.E., Robert, D., Varela, D.E., Lovejoy, C., Darnis, G., Nelson, R.J., and Sastri, A.R., 2012. Current state and trends in Canadian Arctic marine ecosystems: I. Primary production, Climatic Change, 115 (1), 161-178.

Ueno, H., Sato, K., Freeland, H.J., Crawford, W.R., Onishi, H., Oka, E., and Suga, T., 2009. Anticyclonic eddies in the Alaskan Stream, Journal of Physical Oceanography, 39 (4), 934-951. Ullman, D.S. and Cornillon, P.C., 1999. Satellite-derived sea surface temperature fronts on the continental shelf off the northern U.S. coast, Journal of Geophysical Research, 104 (C10), $23459-23478$.

Valeur, H.H., Hansen, C., Hansen, K.Q., Rasmussen, L., and Thingvad, N., 1996. Weather, sea 
and ice conditions in eastern Baffin Bay, offshore northwest Greenland: A review, Tech. Rep. December, Mineral Resources Administration for Greenland, Copenhagen, Denmark.

Van As, D., 2011. Warming, glacier melt and surface energy budget from weather station observations in the Melville Bay region of northwest Greenland, Journal of Glaciology, 57 (202), $208-220$.

Vermeer, K., Butler, R.W., and Morgan, K.H., 1992. Ecology, status, and conservation of marine and shoreline birds on the west coast of Vancouver Island, Canadian Wildlife Service, Occasional Paper, 75 .

Vladykov, V.D., 1933. Biological and oceanographic conditions in Hudson Bay 9. Fishes from the Hudson Bay region (except the coregonidae), Contributions to Canadian Biology and Fisheries, 8 (1), 13-61.

Waite, J.N. and Mueter, F.J., 2013. Spatial and temporal variability of chlorophyll-a concentrations in the coastal Gulf of Alaska, 1998-2011, using cloud-free reconstructions of SeaWiFS and MODIS-Aqua data, Progress in Oceanography, 116, 179-192.

Wall, C.C., Muller-Karger, F.E., Roffer, M.a., Hu, C., Yao, W., and Luther, M.E., 2008. Satellite remote sensing of surface oceanic fronts in coastal waters off west-central Florida, Remote Sensing of Environment, 112 (6), 2963-2976.

Wang, Q., Myers, P.G., Hu, X., and Bush, A.B., 2012. Flow constraints on pathways through the Canadian Arctic Archipelago, Atmosphere-Ocean, 50 (3), 373-385.

Wessel, P. and Smith, W.H.F., 1996. A global, self-consistent, hierachical, high-resolution shoreline database, Journal of geophysical research, 101 (B4), 8741-8743.

Whitney, F., Crawford, W., and Harrison, P., 2005. Physical processes that enhance nutrient transport and primary productivity in the coastal and open ocean of the subarctic NE Pacific, Deep Sea Research Part II: Topical Studies in Oceanography, 52 (5-6), 681-706.

Wong, S.N., Gjerdrum, C., Morgan, K.H., and Mallory, M.L., 2014. Hotspots in cold seas: the composition, distribution and abundance of marine birds in the North American Arctic, Journal of Geophysical Research: Oceans, In Press. 
${ }_{852}$ Wu, Y., Tang, C., and Hannah, C., 2012. The circulation of eastern Canadian seas, Progress in 853 Oceanography, 106, 28-48. 


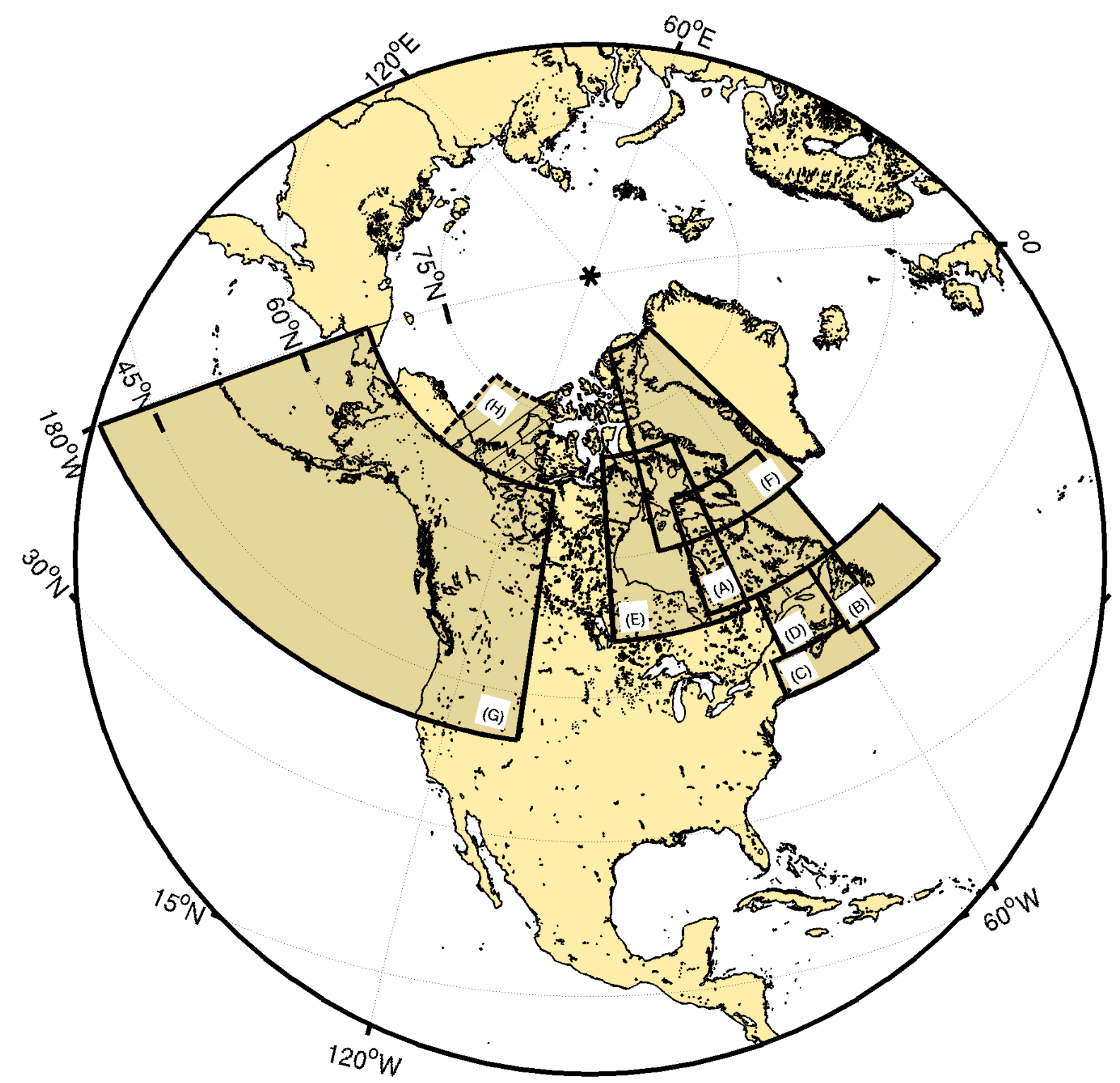

Fig. 1 Global map of the studied areas: A) Hudson Strait and Labrador Shelf $\left(52-65^{\circ} \mathrm{N}, 59-54^{\circ} \mathrm{W}\right)$, B) Newfoundland Shelf $\left.\left(44-52^{\circ} \mathrm{N}, 60-51^{\circ} \mathrm{W}\right), \mathrm{C}\right)$ Scotian Shelf and Gulf of Maine $\left(41-45^{\circ} \mathrm{N}, 72-58^{\circ} \mathrm{W}\right)$, D) Gulf of St. Lawrence $\left.\left(45-52^{\circ} \mathrm{N}, 70-55^{\circ} \mathrm{W}\right), \mathrm{E}\right)$ Hudson Bay and Foxe Basin $\left(51-71^{\circ} \mathrm{N}, 96-72^{\circ} \mathrm{W}, \mathrm{F}\right)$ Baffin Bay $\left.\left(60-82^{\circ} \mathrm{N}, 85-50^{\circ} \mathrm{W}\right), \mathrm{G}\right)$ Northeast Pacific Ocean $\left(40-67^{\circ} \mathrm{N}, 180-110^{\circ} \mathrm{W}\right)$. The Beaufort Sea, $\mathrm{H}\left(67-76^{\circ} \mathrm{N}, 145-115^{\circ} \mathrm{W}\right)$, is not under the scope of the present study because the region is under investigation in a separate study.

in 


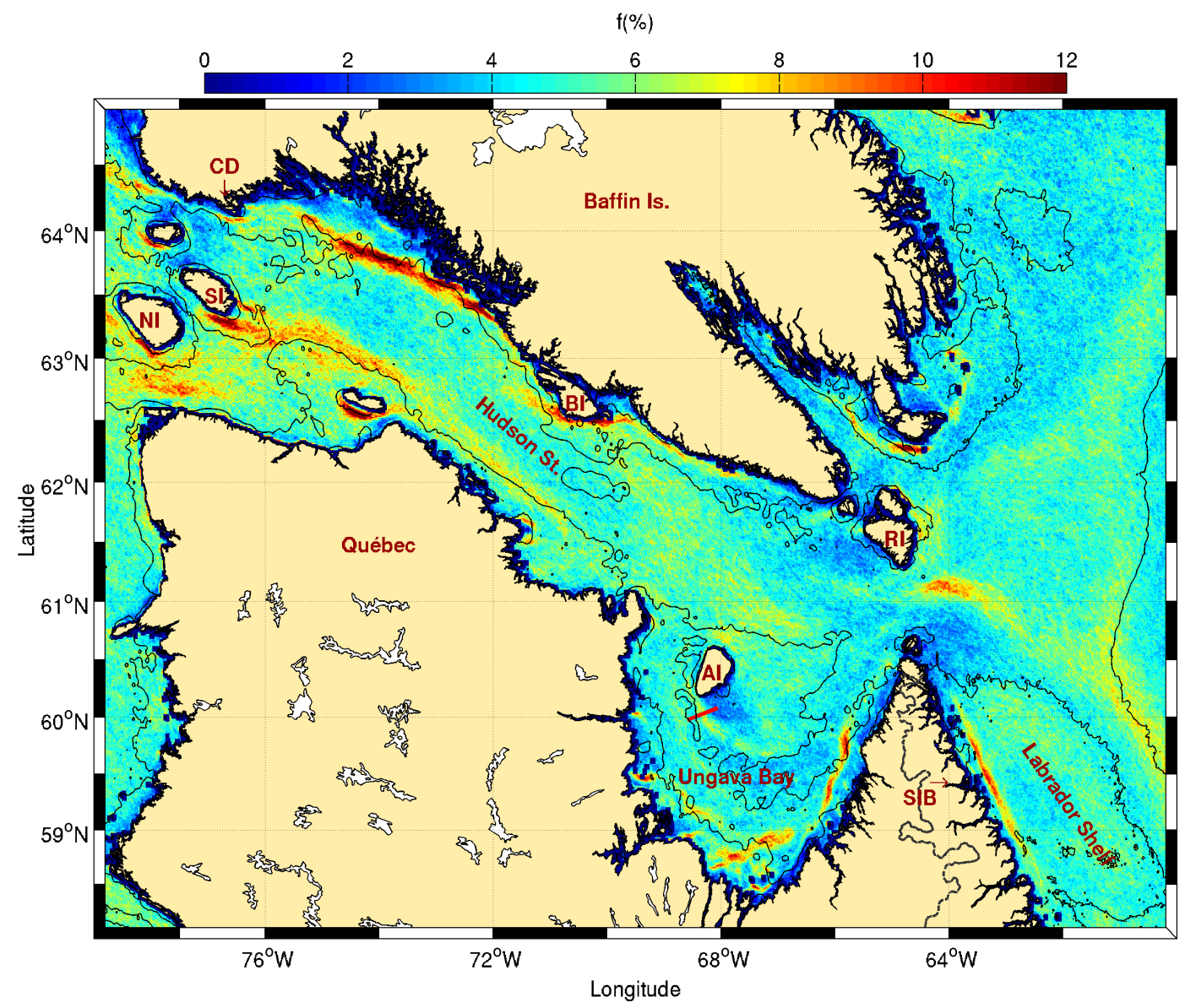

Fig. 2 Mean frontal frequency (1986-2010) for the Hudson Strait, Ungava Bay and Northern Labrador Shelf. Isobaths $50 \mathrm{~m}$, $200 \mathrm{~m}$ and $1000 \mathrm{~m}$ are drawn. Location of Cape Dorset (CD), Baffin, Salisbury (SI), Nottingham (NI), Big (BI), Resolution (RI) and Akpatok (AI) islands and Seven Islands Bay (SIB) are shown. The red line correspond to the cross-front transect described in Taggart et al. (1989). 


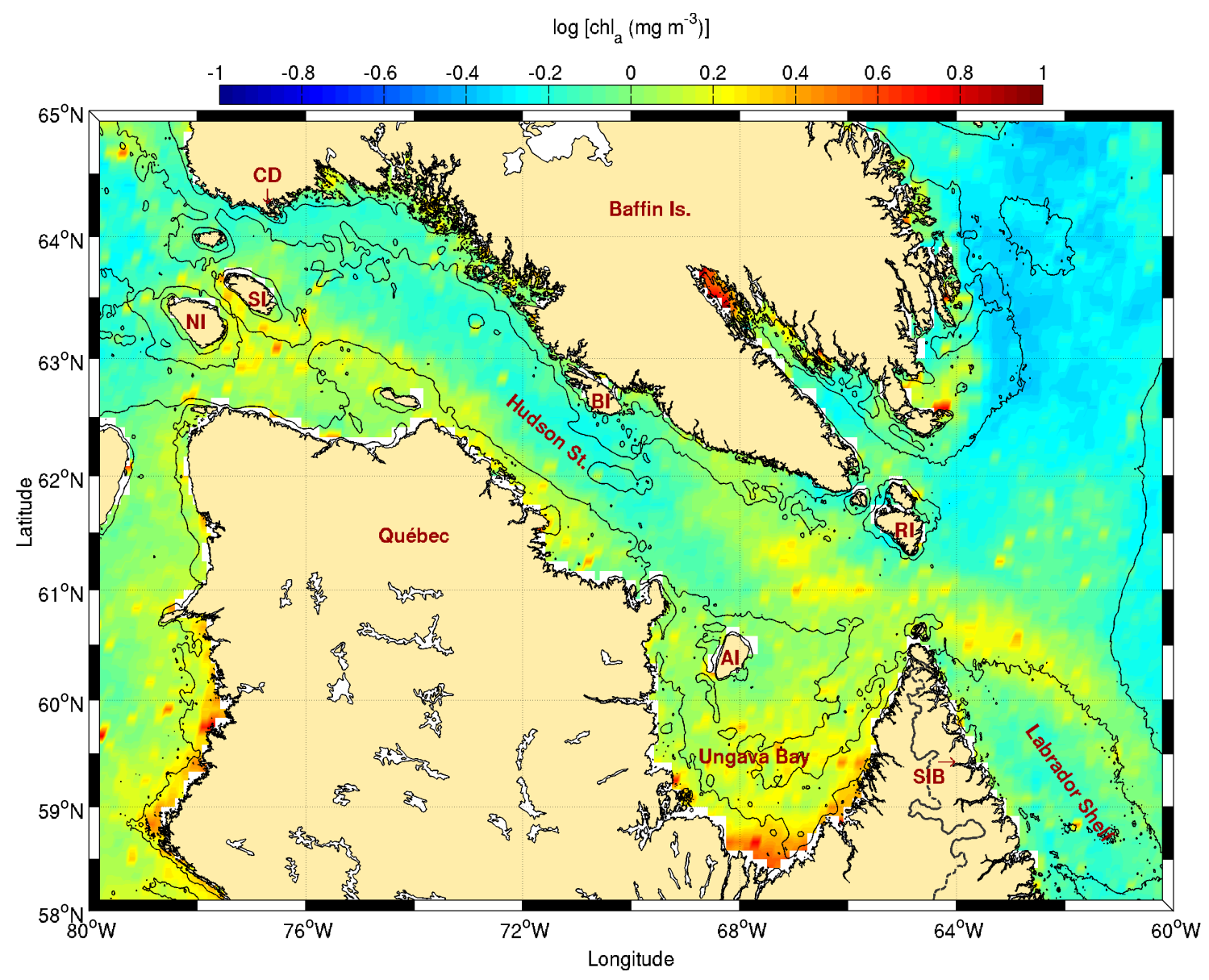

Fig. 3 Chl-a concentration climatology (1998-2010) for the Hudson Strait, Ungava Bay and Northern Labrador Shelf. Isobaths $50 \mathrm{~m}, 200 \mathrm{~m}$ and $1000 \mathrm{~m}$ are drawn. See Fig. 2 for acronyms. 


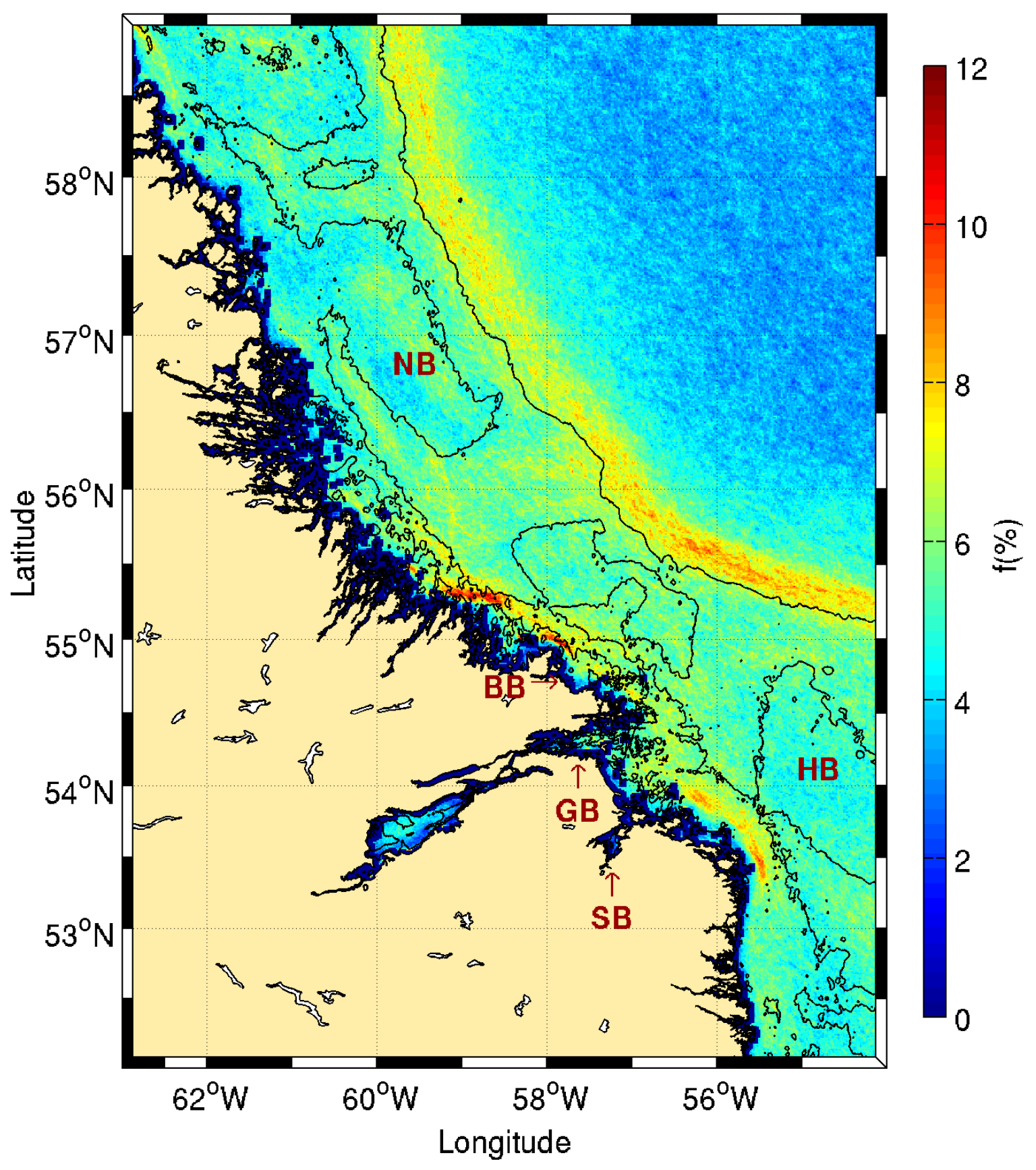

Fig. 4 Mean frontal frequency (1986-2010) for the Southern Labrador Shelf. Isobaths $50 \mathrm{~m}, 200 \mathrm{~m}$ and $1000 \mathrm{~m}$ are drawn. Location of Nain (NB) and Hamilton (HB) banks and Byron (BB), Groswater (GB) and Sandwich (SB) bays are shown. 


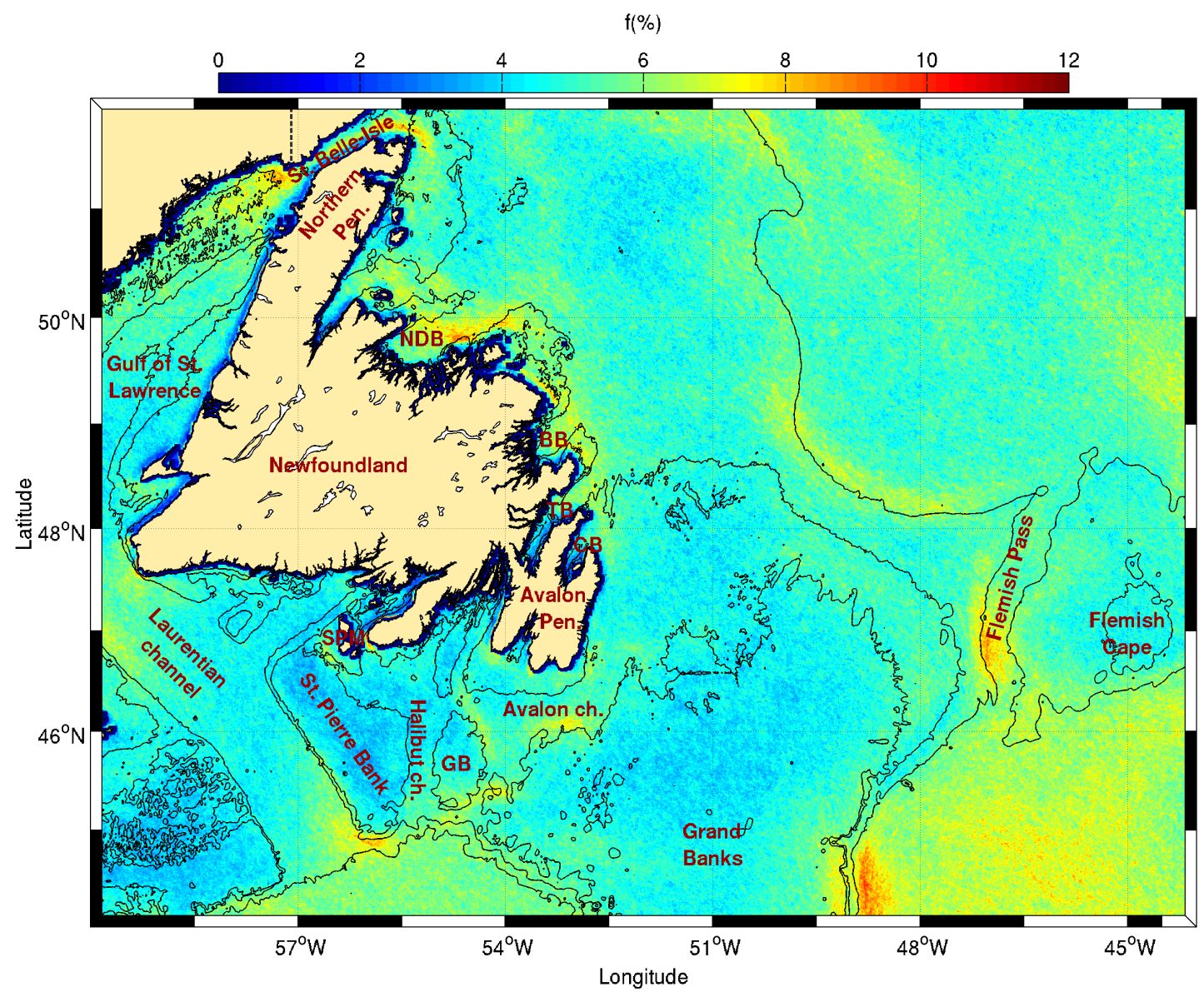

Fig. 5 Mean frontal frequency (1986-2010) for the Newfoundland Shelf. Isobaths $100 \mathrm{~m}$ and $1000 \mathrm{~m}$ are drawn. Location of Strait of Belle-Isle, Northern and Avalon peninsulas, Gulf of St. Lawrence, Laurentian, Avalon and Halibut channels, St. Pierre Bank, Grand and Green (GB) banks, St. Pierre and Miquelon islands (SPM) along with Notre-Dame (NDB), Bonavista (BB), Trinity (TB) and Conception (CB) bays are shown. 


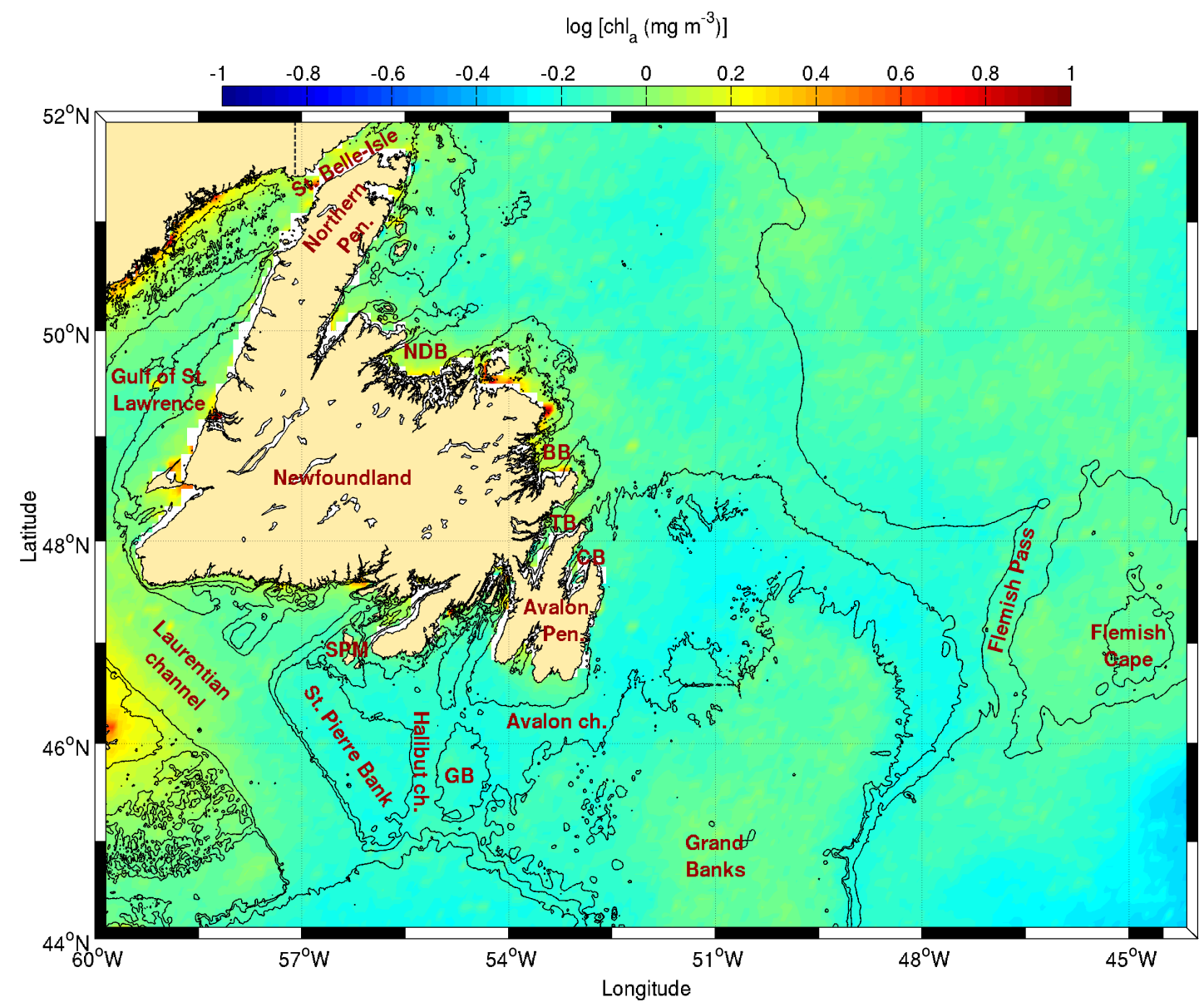

Fig. 6 Chl- $a$ concentration climatology (1998-2010) for the Inner Newfoundland Shelf. Isobaths $100 \mathrm{~m}$ and $1000 \mathrm{~m}$ are drawn. See Fig. 5 for acronyms. 


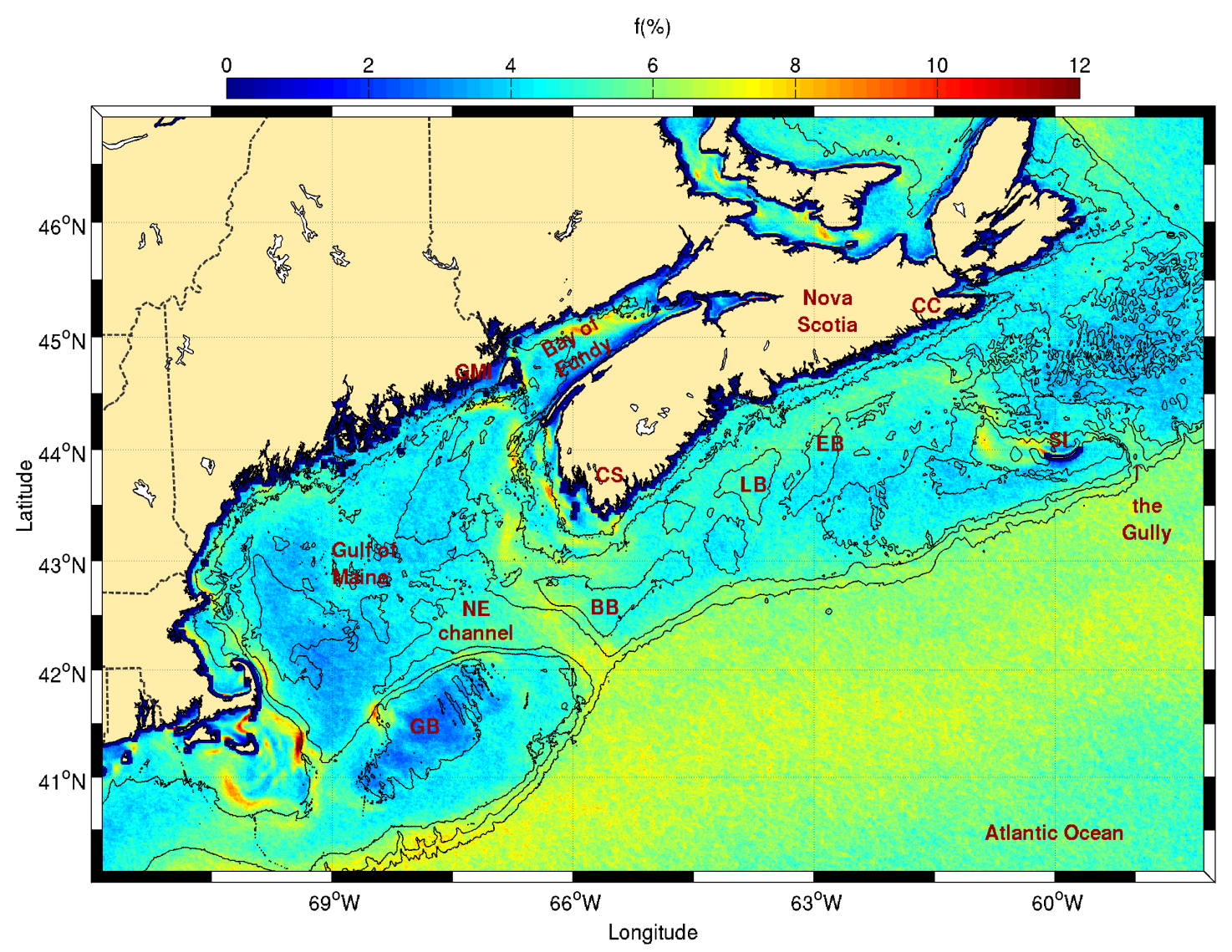

Fig. 7 Mean frontal frequency (1986-2010) for the Scotian Shelf, Gulf of Maine and Bay of Fundy. Isobaths $50 \mathrm{~m}, 100 \mathrm{~m}$, $200 \mathrm{~m}$ and $1000 \mathrm{~m}$ are drawn. Location of the Northeast Channel, Cape Canso (CC) and Cape Sable (CS), the Gully, Sable (SI) and Grand Manan (GMI) Islands, Lehave (LB) and Emerald (EB) basins and Browns (BB) and George (GB) banks are shown. 


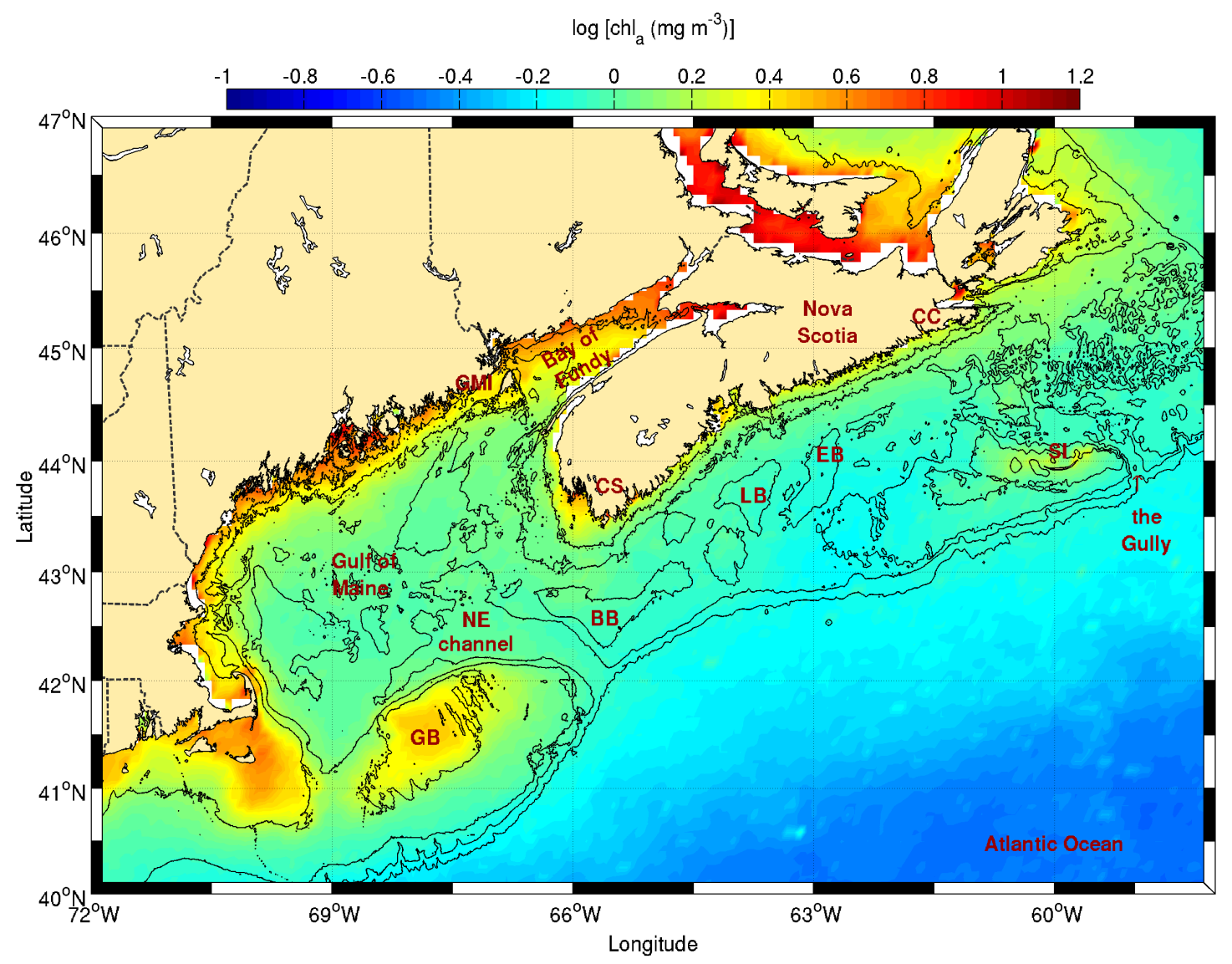

Fig. 8 Chl- $a$ concentration climatology (1998-2010) for the Scotian Shelf and the Gulf of Maine. Isobaths $50 \mathrm{~m}, 100 \mathrm{~m}$, $200 \mathrm{~m}$ and $1000 \mathrm{~m}$ are drawn. See Fig. 7 for acronyms. 


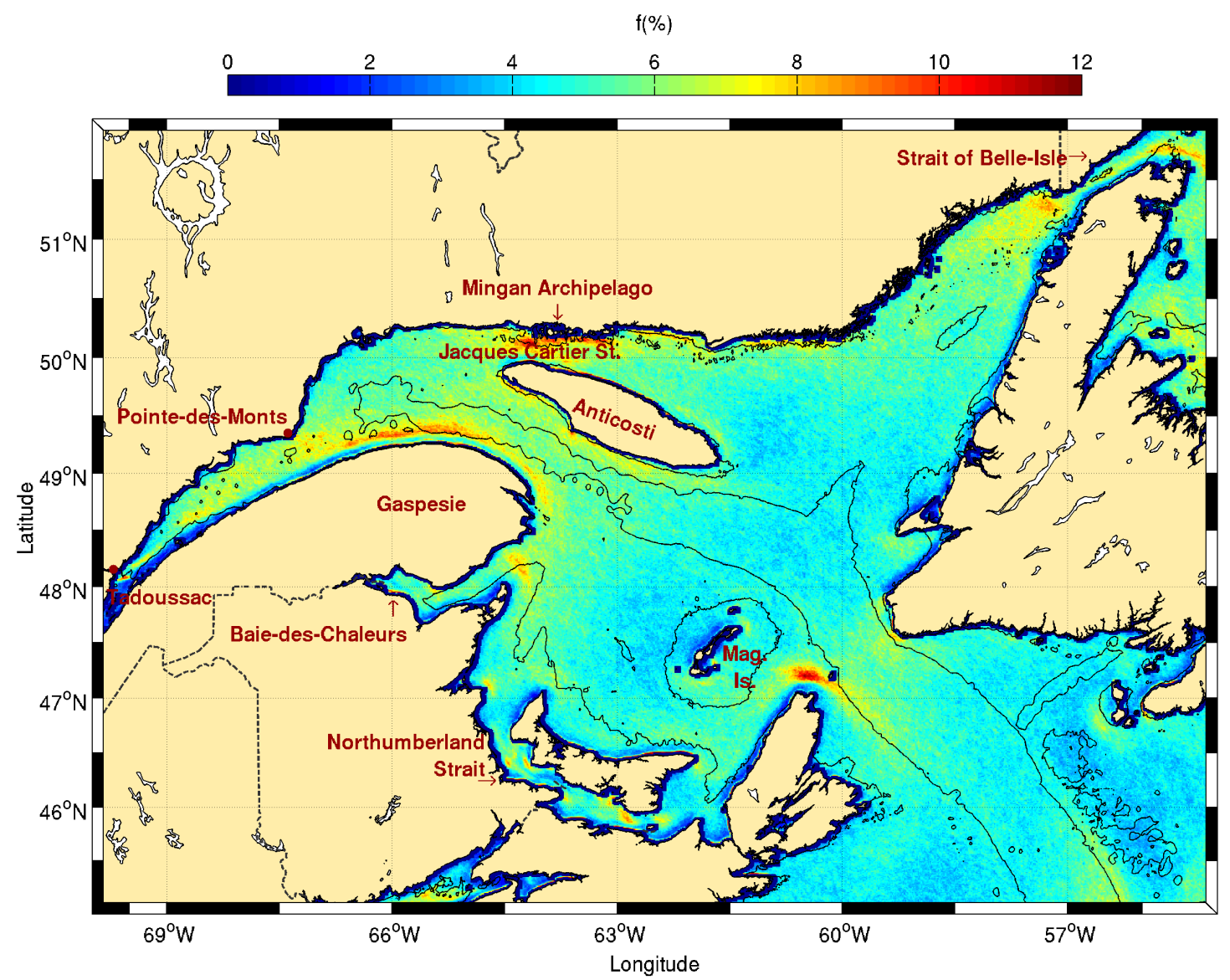

Fig. 9 Mean frontal frequency (1986-2010) for the Gulf of St. Lawrence. Isobaths $50 \mathrm{~m}$ and $300 \mathrm{~m}$ are drawn. 


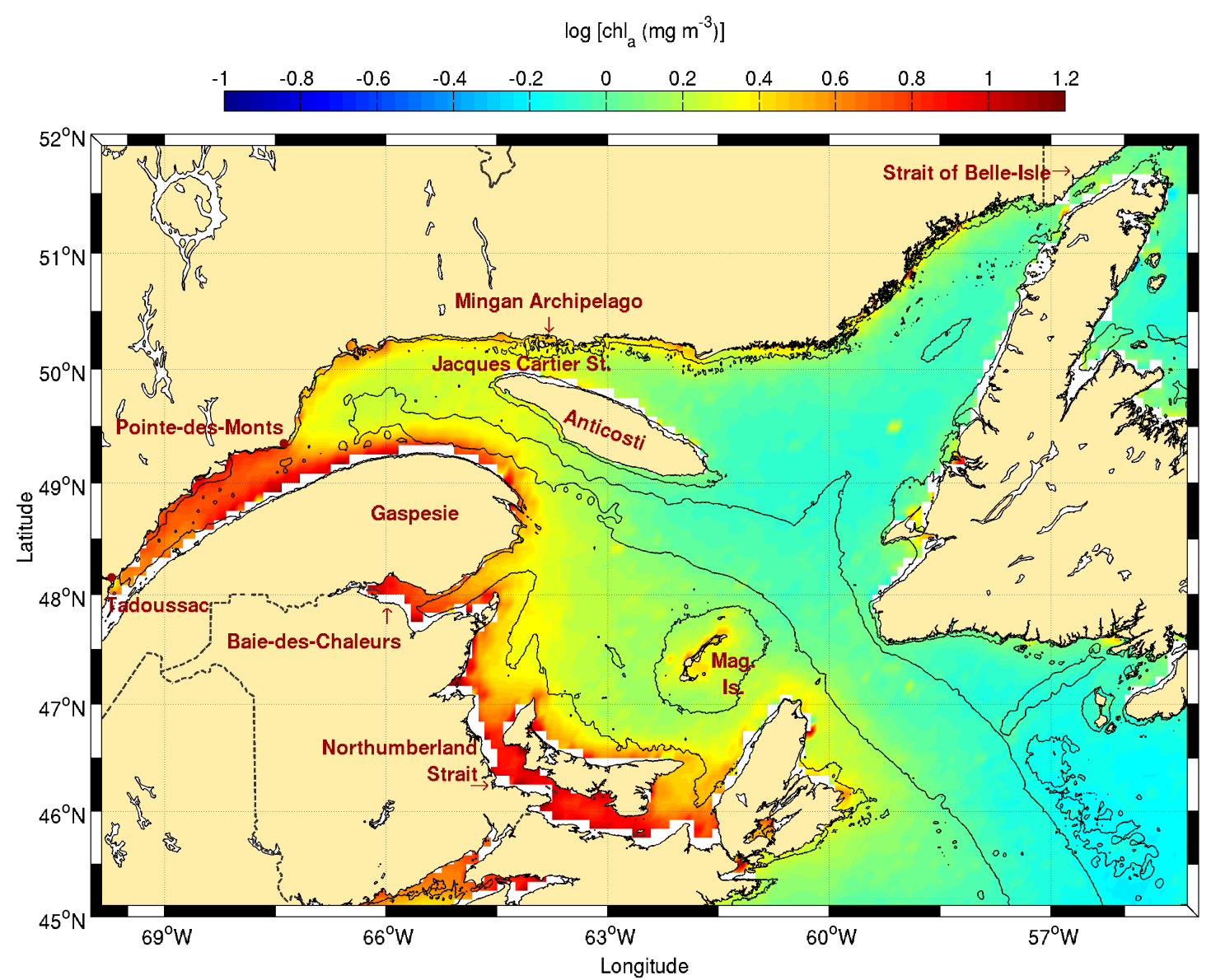

Fig. 10 Chl- $a$ concentration climatology (1998-2010) for the Gulf of St. Lawrence. Isobaths $50 \mathrm{~m}$ and $300 \mathrm{~m}$ are drawn. 


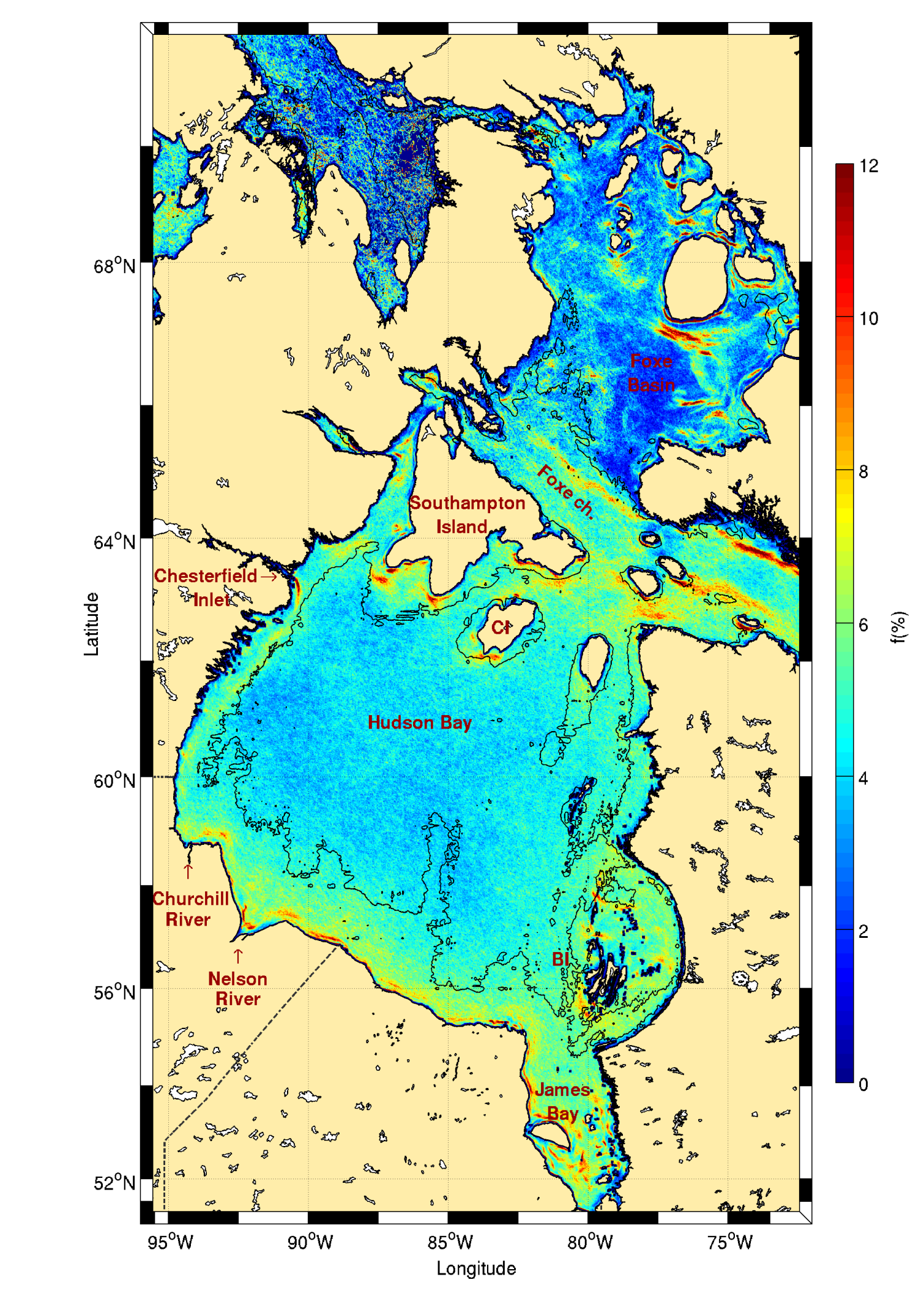

Fig. 11 Mean frontal frequency (1986-2010) for the Hudson Bay. The isobath $100 \mathrm{~m}$ is drawn. The Belcher and Coat islands are identified with the acronym BI and CI respectively.

45

(n) 


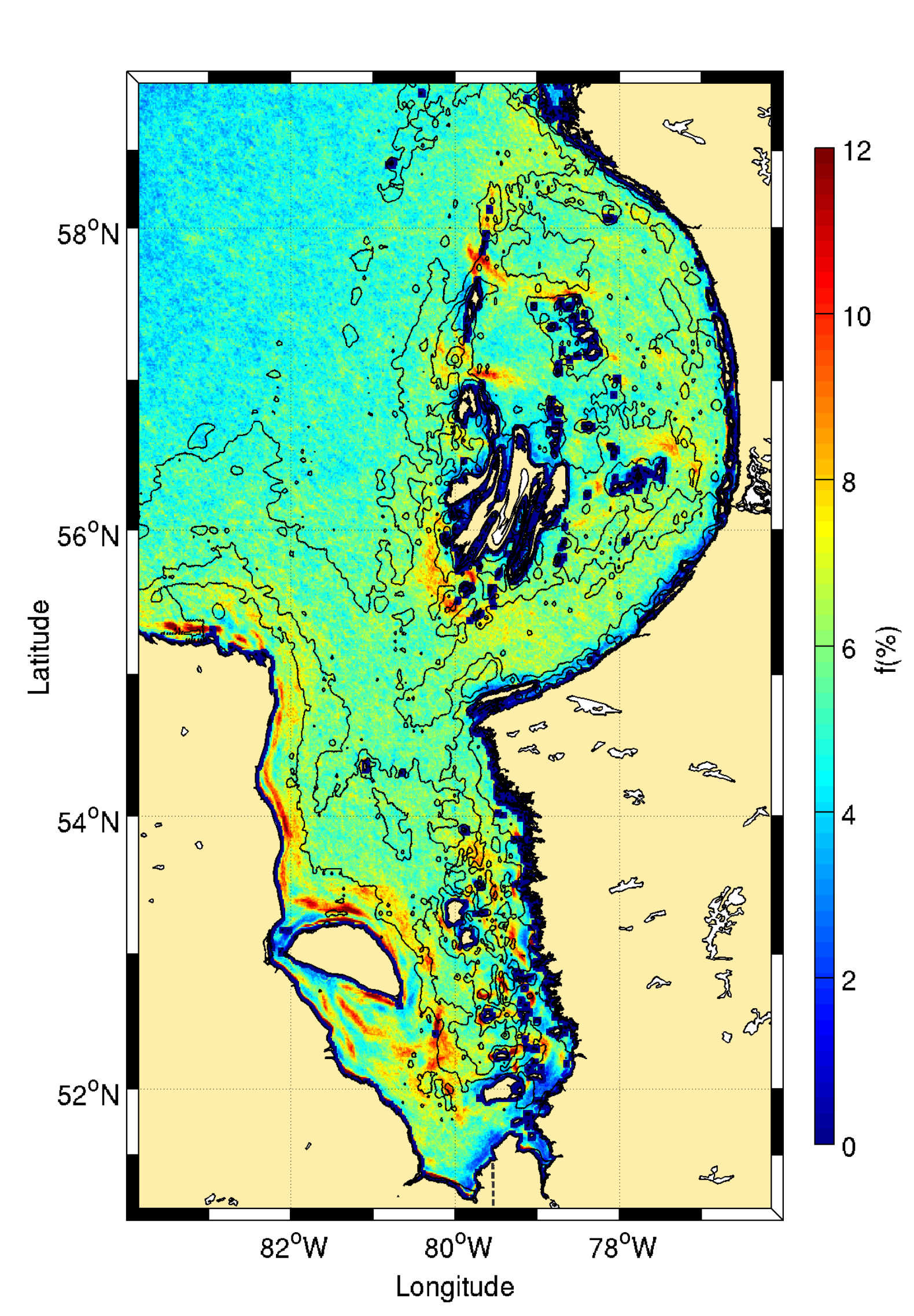

Fig. 12 Details of Belcher Islands and James Bay from Figure 11. Isobaths $25 \mathrm{~m}, 50 \mathrm{~m}$ and $100 \mathrm{~m}$ are drawn. 


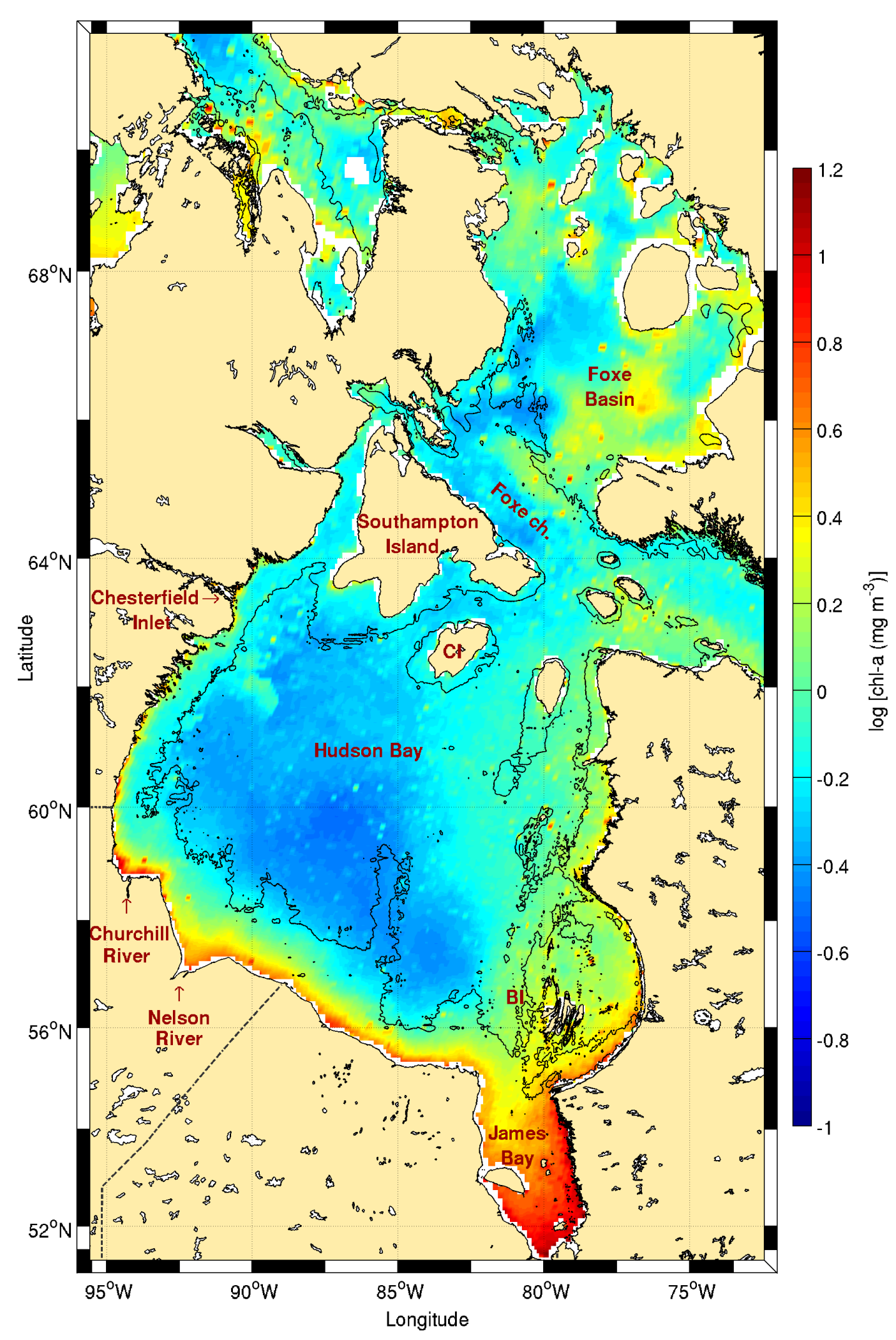

Fig. 13 Chl- $a$ concentration climatology (1998-2010) for the Hudson Bay. The isobath $100 \mathrm{~m}$ is drawn. The Belcher and

Coat islands are identified with the acronym BI and CI respectively. 


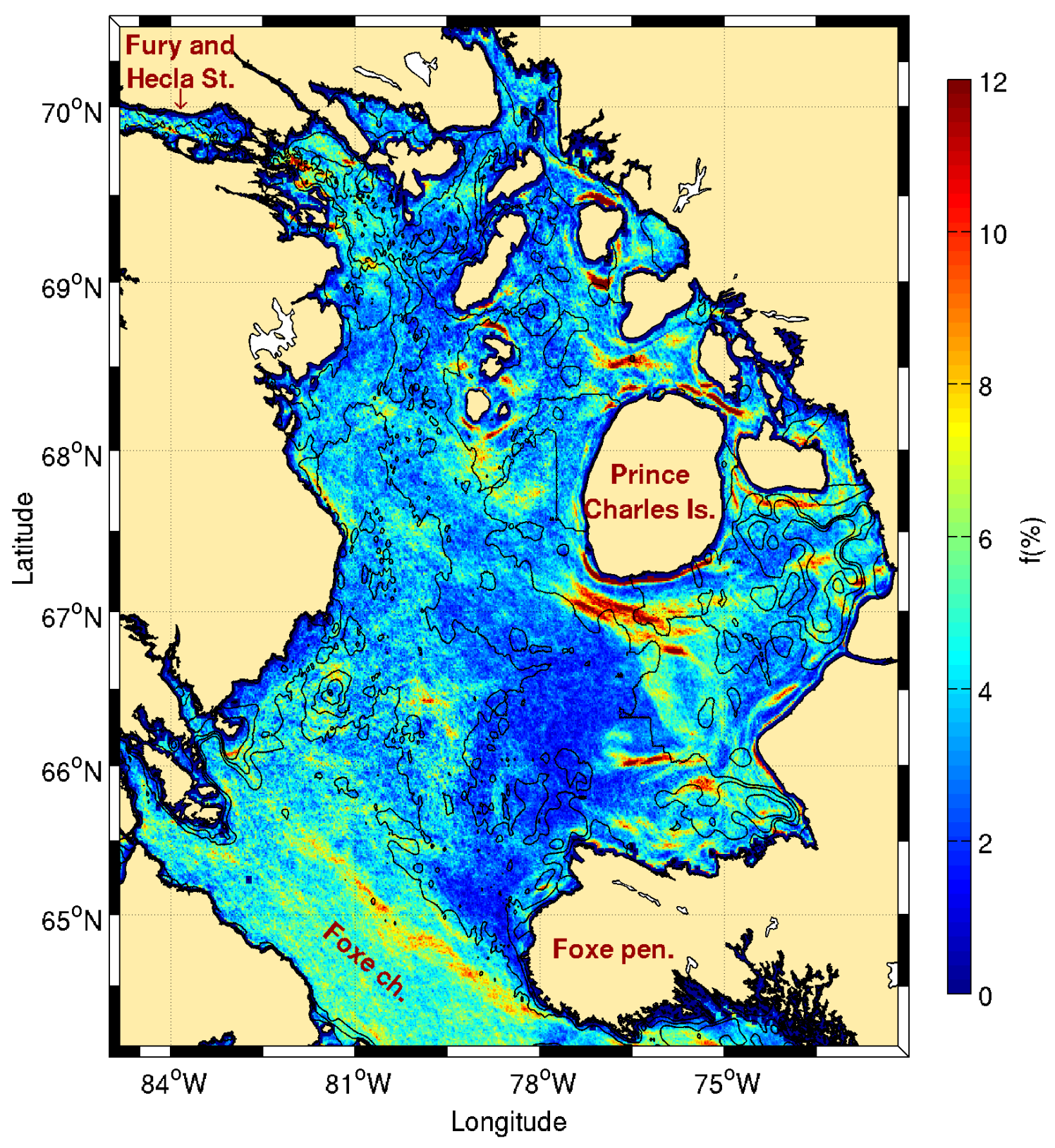

Fig. 14 Details of Foxe Basin from Figure 11. Isobaths $25 \mathrm{~m}, 50 \mathrm{~m}$ and $100 \mathrm{~m}$ are drawn. 


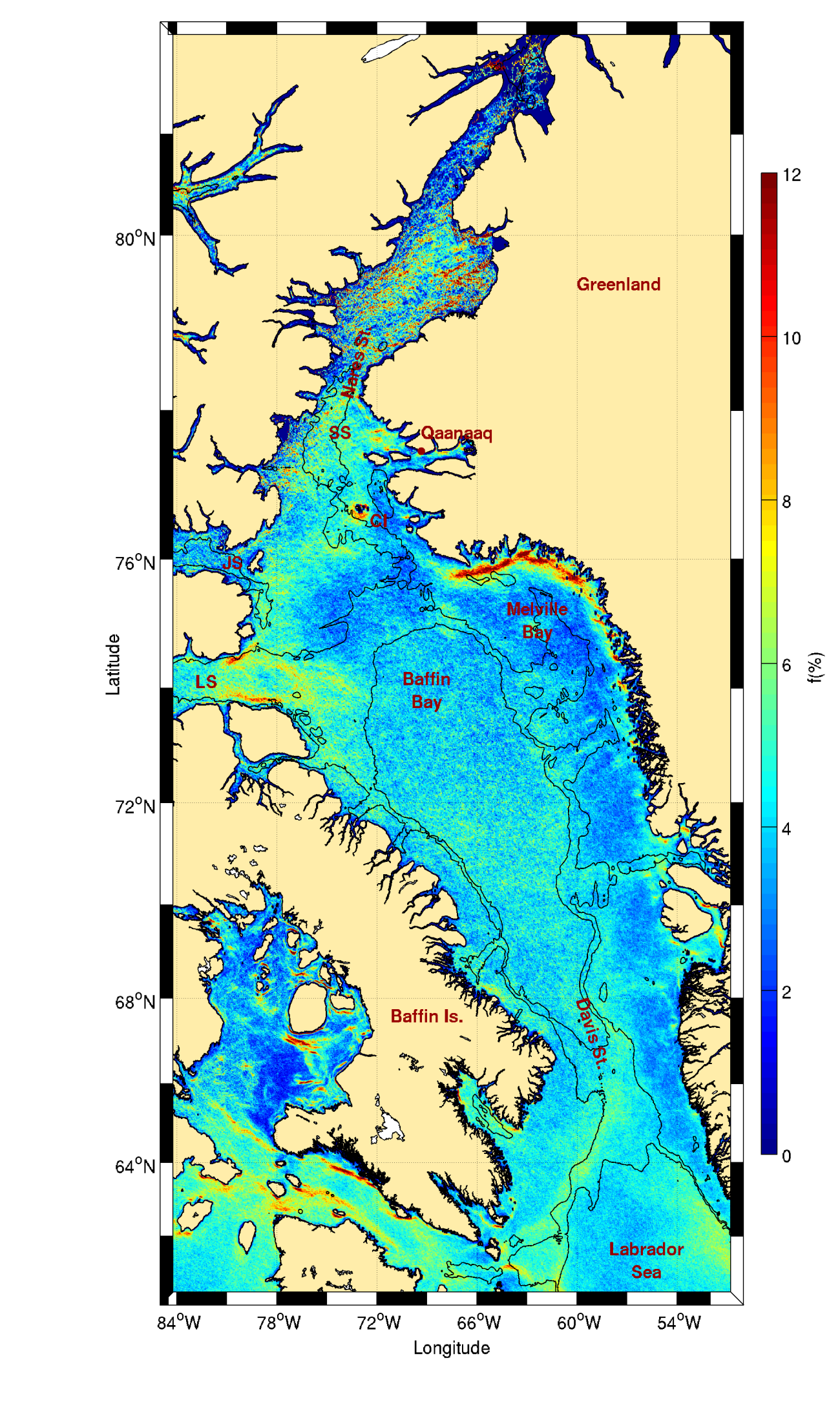

Fig. 15 Mean frontal frequency (1986-2010) for the Baffin Bay. Isobaths $500 \mathrm{~m}$ and $1000 \mathrm{~m}$ are drawn. The location of the Carey Islands (CI), Nares and Davis straits and Smith (SS), Jones (JS) and Lancaster (LS) sounds are shown.

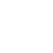

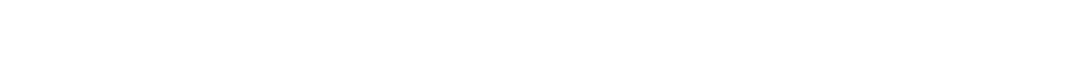

(1)

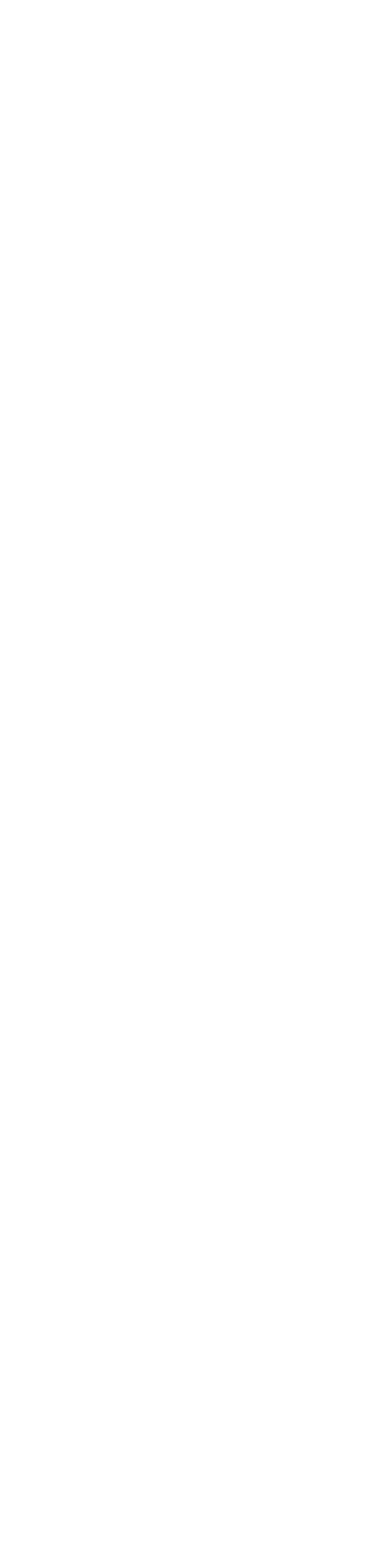

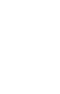

Carey Islands (CI), Nares and Davis straits and Smith (SS), J9

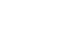




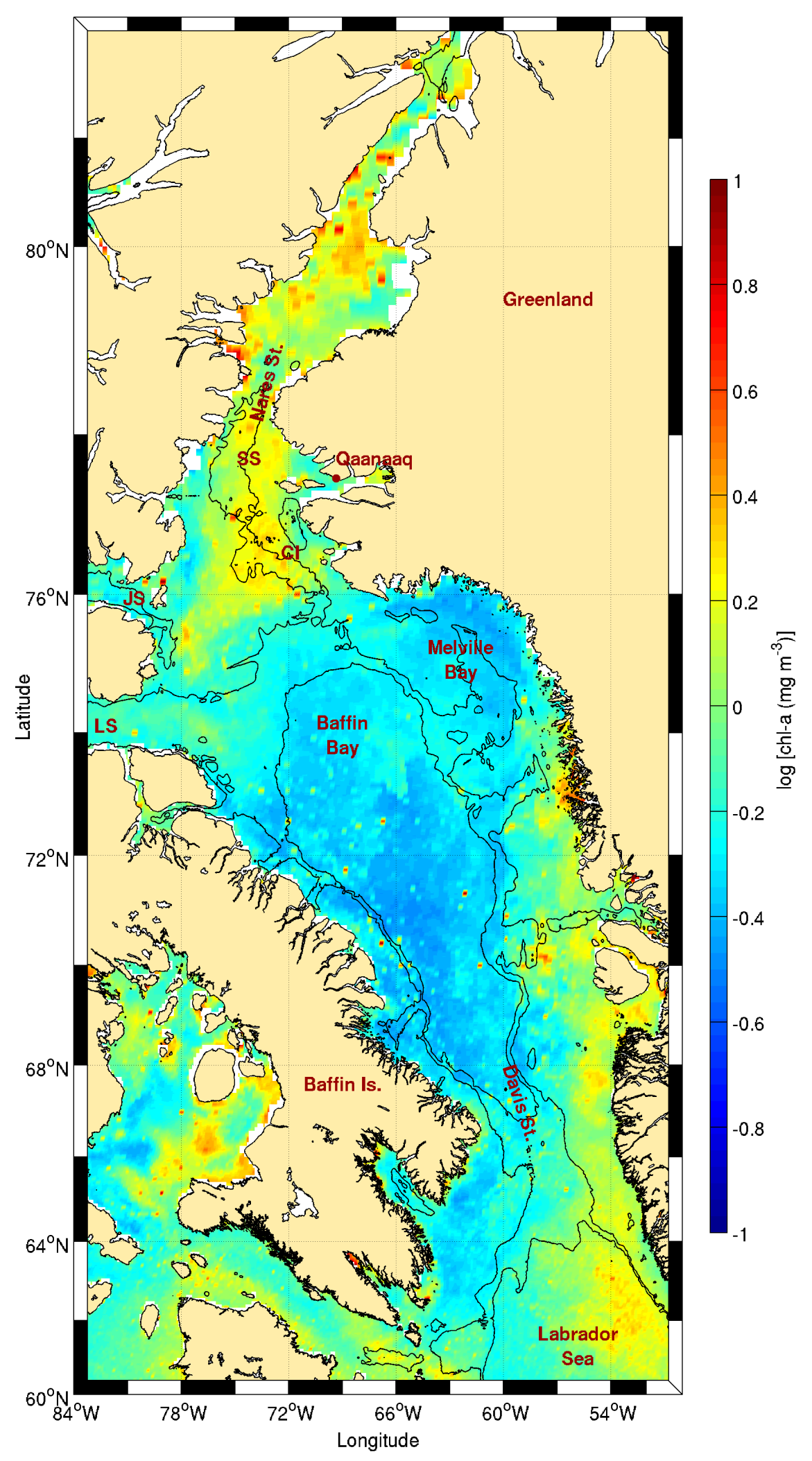

Fig. 16 Chl-a concentration climatology (1998-2010) for the Baffin Bay. Isobaths $500 \mathrm{~m}$ and $1000 \mathrm{~m}$ are drawn. See Figure 15 for acronyms. 


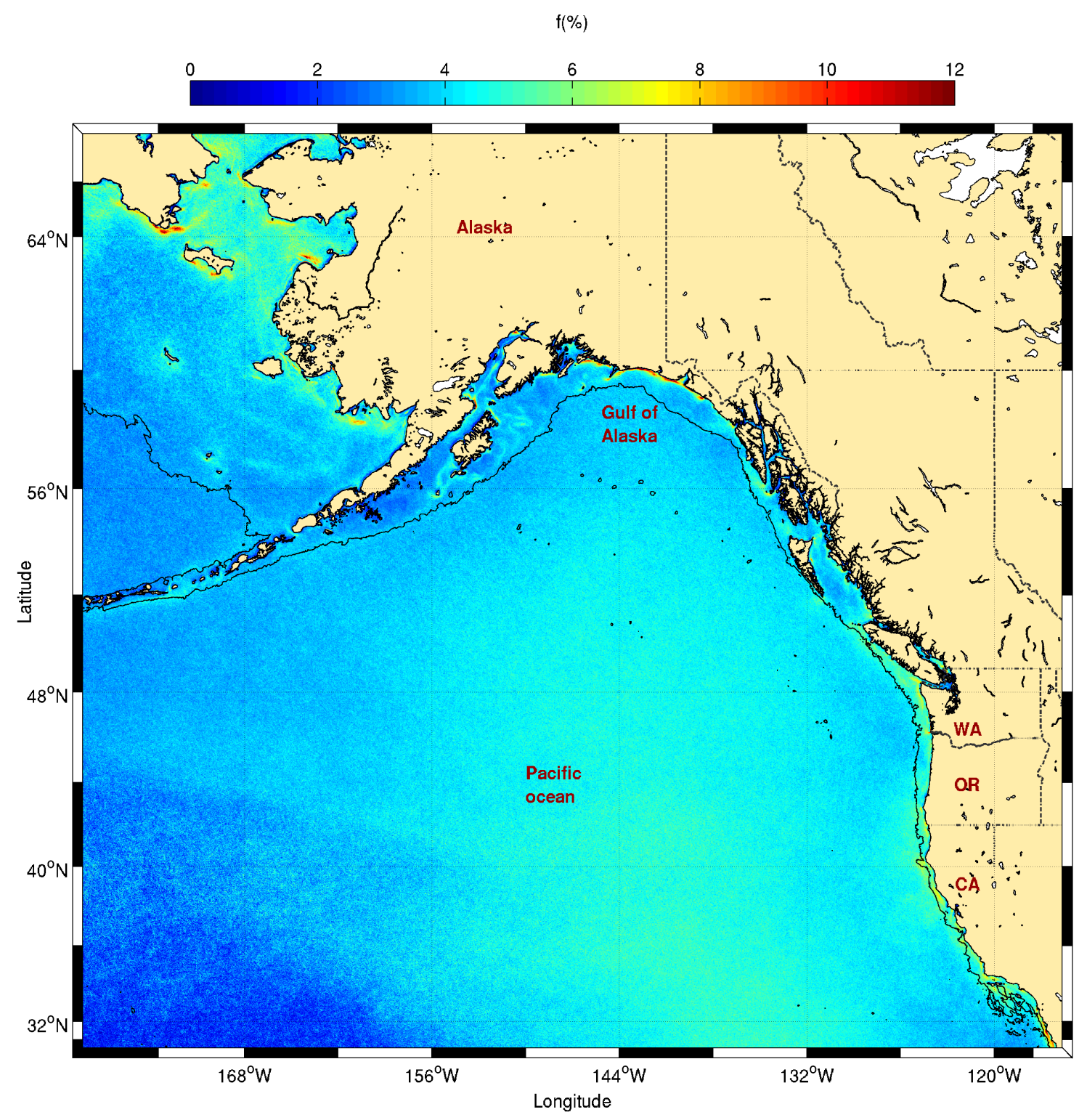

Fig. 17 Mean frontal frequency (1986-2010) for the Northeastern Pacific Ocean. Isobath $1000 \mathrm{~m}$ (shelf break) is drawn. Here, the Washington (WA), Oregon (OR) and California (CA) states are also shown. 


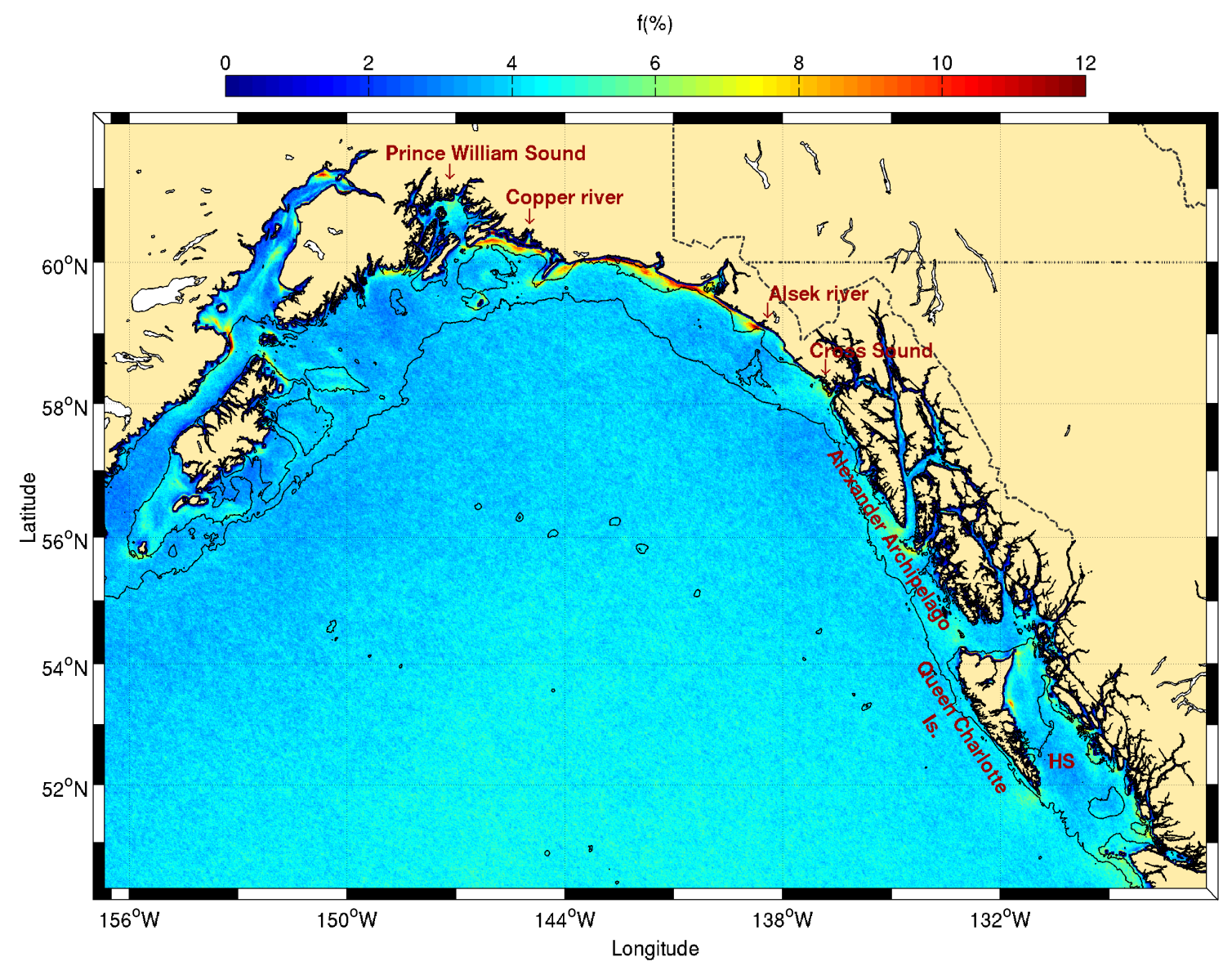

Fig. 18 Details of the Gulf of Alaska from Figure 17. Isobaths $100 \mathrm{~m}$ and $1000 \mathrm{~m}$ are drawn. Hecate Strait is identified with the acronym HS. 


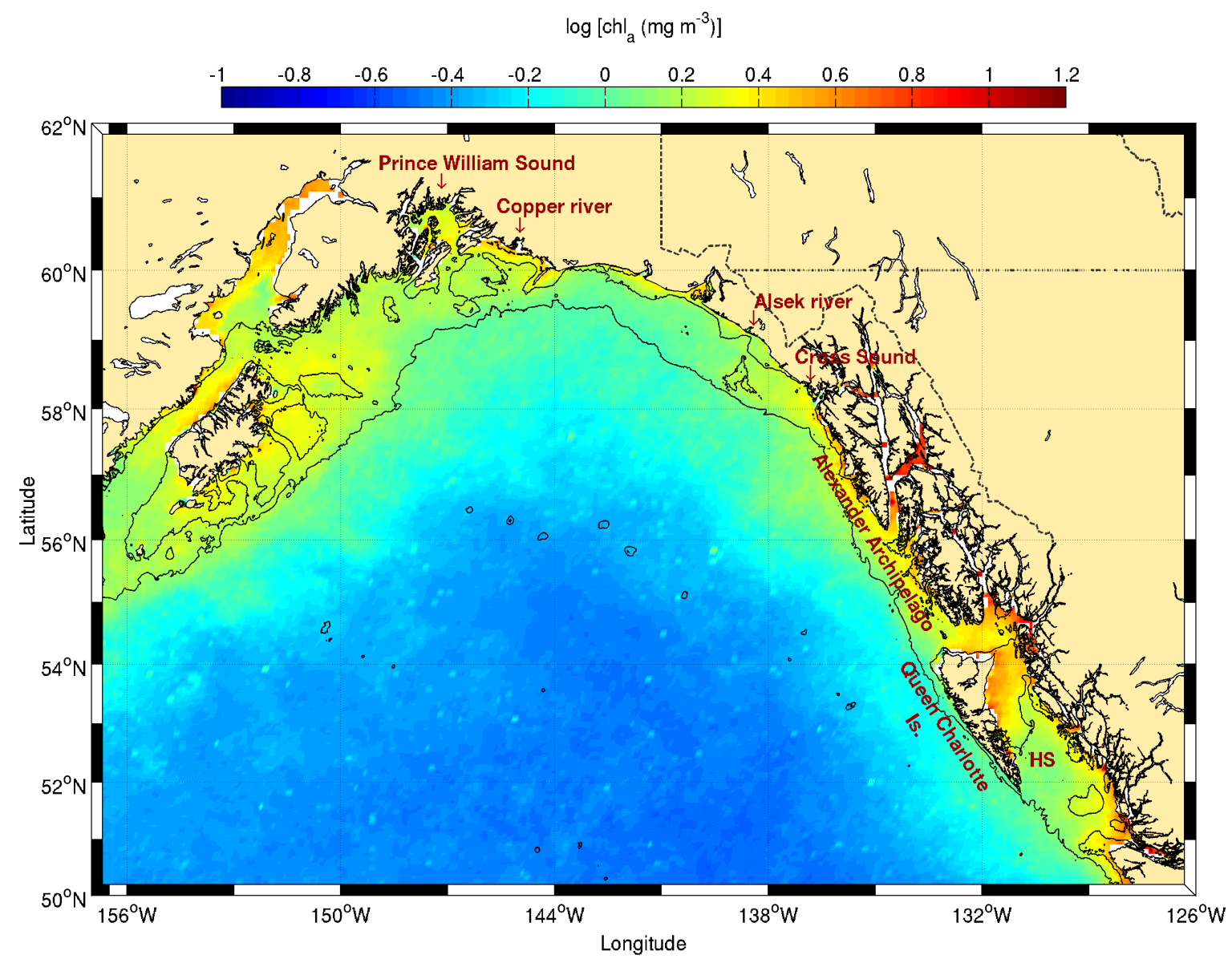

Fig. 19 Chl- $a$ concentration climatology (1998-2010) for the Gulf of Alaska. Isobaths $100 \mathrm{~m}$ and $1000 \mathrm{~m}$ are drawn. Hecate Strait is identified with the acronym HS. 


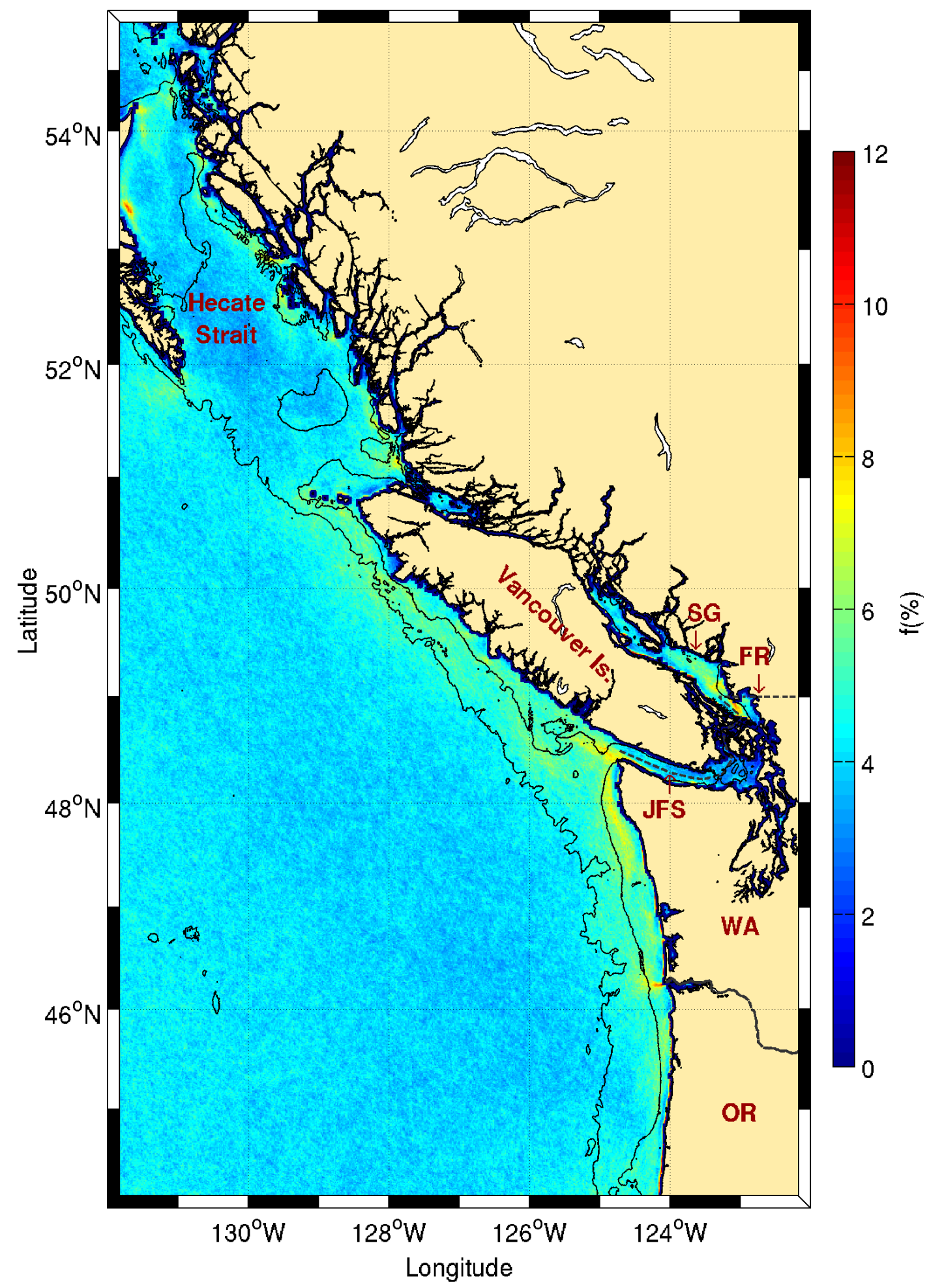

Fig. 20 Details of Vancouver Island and its surroundings from Figure 17. Isobaths $100 \mathrm{~m}$ and $1000 \mathrm{~m}$ are drawn. Location of Hecate strait, the Strait of Georgia (SG), the Fraser river (FR) and the Juan de Fuca Strait (JFS) are shown along with the Washington (WA) and Oregon (OR) states. 


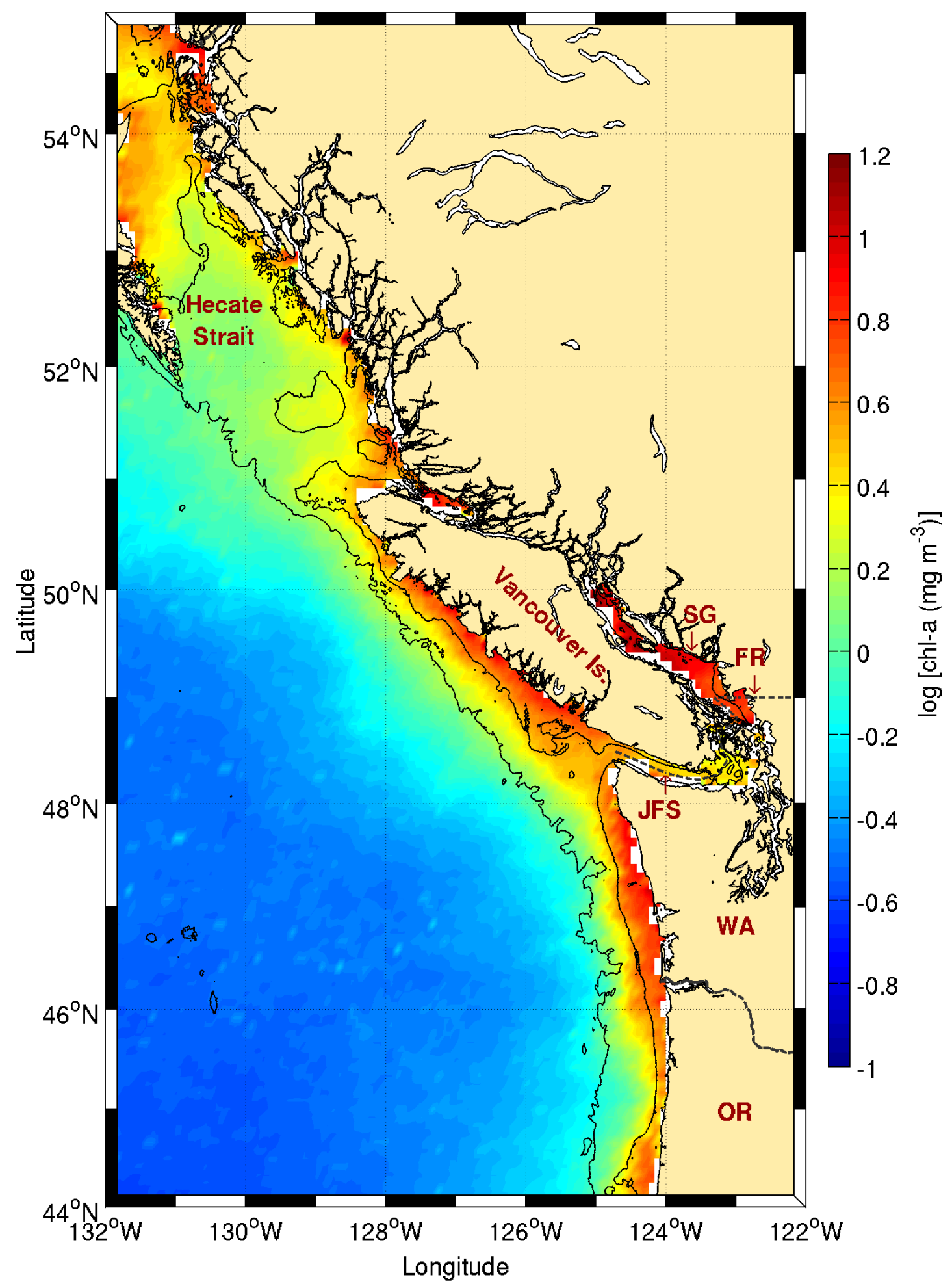

Fig. 21 Chl- $a$ concentration climatology (1998-2010) around Vancouver Island. Isobaths $100 \mathrm{~m}$ and $1000 \mathrm{~m}$ are drawn. See Figure 20 for acronyms. 